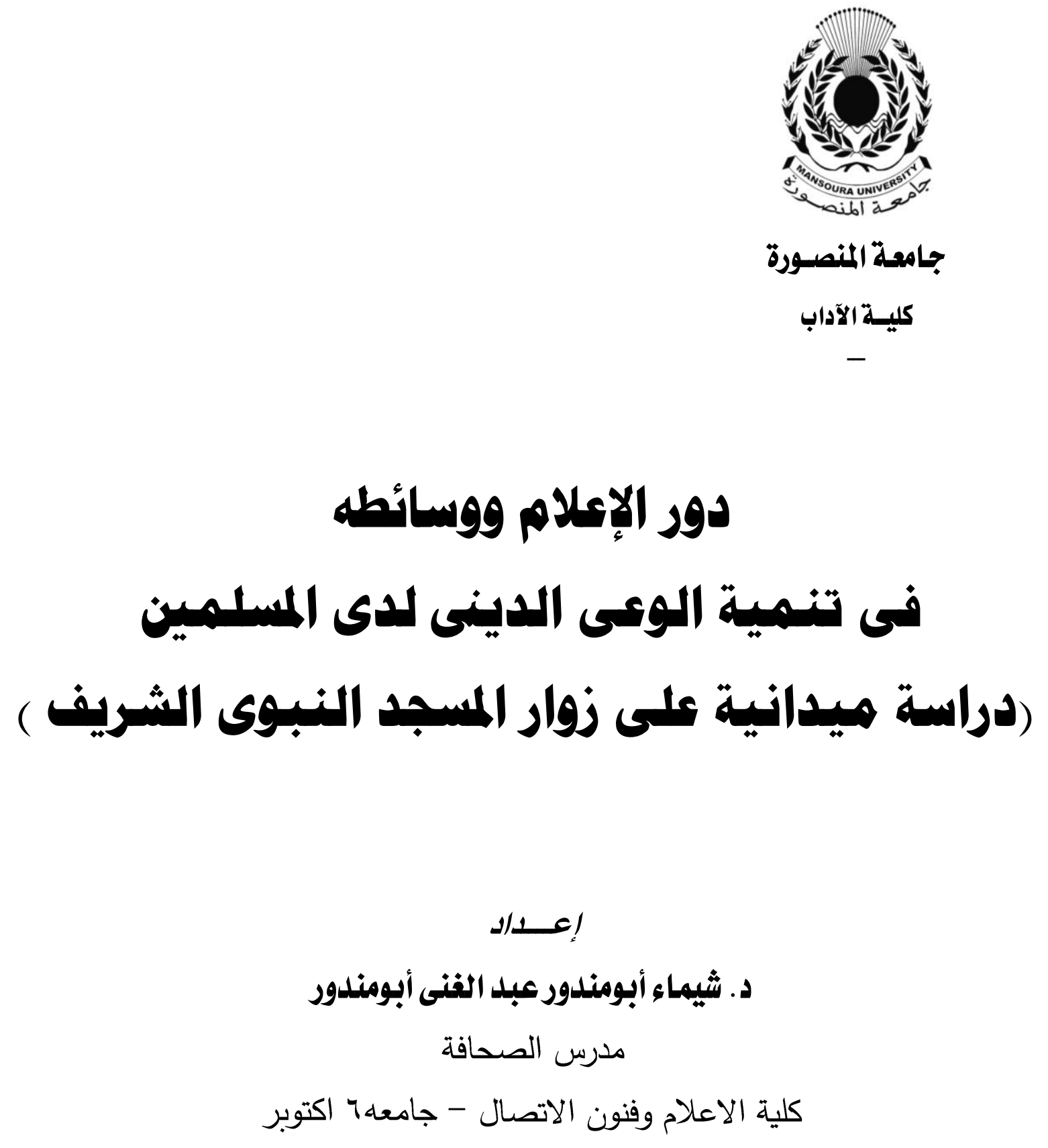

مجـلة كلــية الآداب - جـامعـة المنصــورة

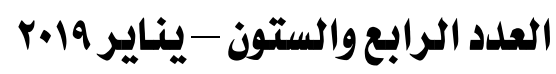




\section{دور الإعلام ووسائطه فى تنمية الو عى الدينى لدى المسلمين (دراسة ميدانية على زوار المسجد النبوى الشريف )}

د. شيماء أبومندور عبد الفنى أبومندور.

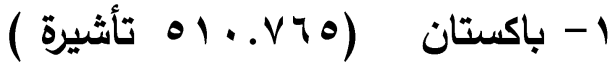

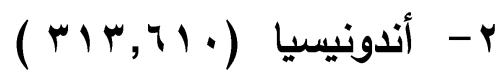

$$
\begin{aligned}
& \text { r } \\
& \text { ع - ماليزيا (I, }
\end{aligned}
$$

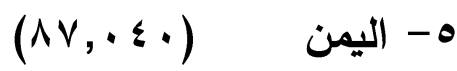

$$
\begin{aligned}
& \text { צ- } \\
& \text { ( } \\
& \text { 1- بنجلاديش ( } \\
& \text { a الإمارات }
\end{aligned}
$$

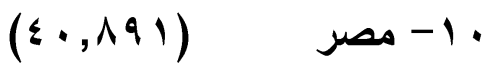

كما أن زيارة المسجد النبوى وزيارة قبر

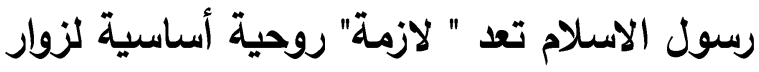

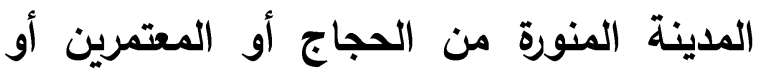

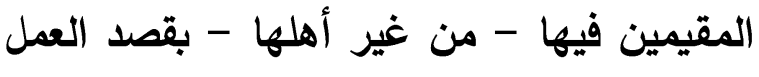
، بل إن بعض قاصدى الحج من غير المتعمين

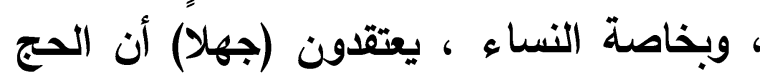
إنما هو زيارة قبر الرسول صلى الله عليه و سلم ـ ويتضح ذلك فى مصر - مثلاً ( وهى من أولى الهى و أكبر الدول الاسلامية )

ورغم الخطأ الفادح في فهم بعض العامة خاصة النساء في أرياف مصر وقراها ونجوعها لمناسك الحج، ألا أن النظرة السطحية العامة لما فيأ

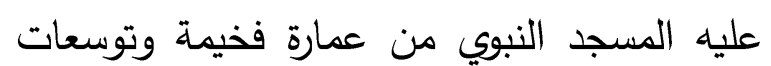
غير مسبوقة وتجهيزات داخلية أخاذة قد تثنغل

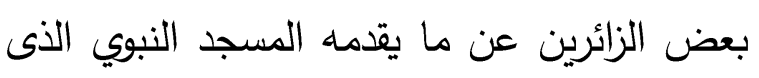

أولاً : الإطار المنهجي والنظري للدراسة :

أ- مدخل إلى موضوع الدراسة:

تتناول هذه الدراسة " دور الاعلام فى هوطع لاعل

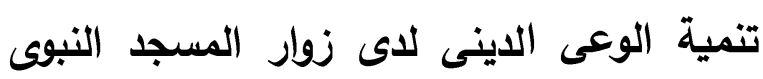
بالمدينة المنورة (التى أسسها رسول الاستلام لمحل

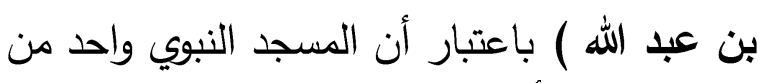

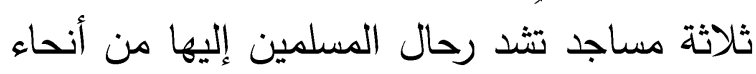
العالم و أن زيارته و المسجد الحرام لاتتقطع ليلاً

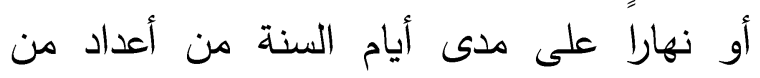

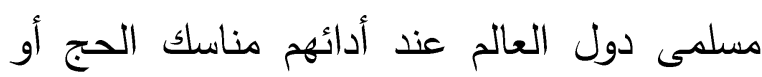
العمرة أو بشكل فردى كواجب و مسحب لكلم لكل مسلم ، و قد زادت هذه الأعداد فى السنوات الأخيرة بفعل تقدم و سهولة وسائل المواصلات من أغلب دول العالم إلى المملكة العربية السعودية أرض الحرميين الثريفين (الحرم الدكى و الحرم النبوى ) لدرجة أن إحصائيات " مؤشر العمرة العرين

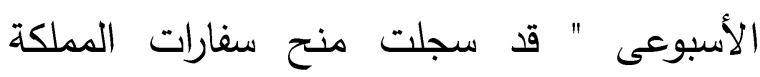
لمسلمين من خارج الدولة تأثيرات عمرة خلال

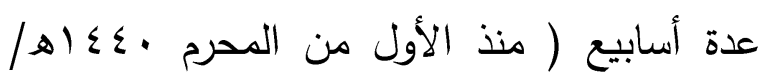

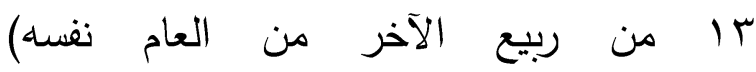
تأشيرة لمسلمين من جنسيات R, Y V,VYN متعددة فى مقدمتها الدول التالية'

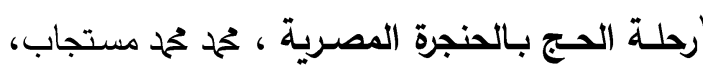

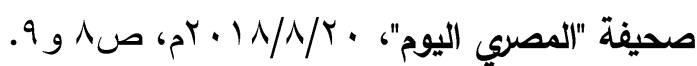




\section{يعد أول مسجد في الإسلام من علوم شرعية ب- أهمية الاراسة:}

تأتي أهمية هذه الدراسة من الأهمية الكبرى التي يوليها المسلمون في أنحاء العالم للمسجد النبوي باعتباره أول مسجد في الإسلام بناه الرسول بـ وجعله متعدد الفوائد والاستخدامات لخدمة المسلمين، فقد كان المسجد رغم بساطته ]بنى بالطوب اللبن وسقف بالجريد وأعمدته من

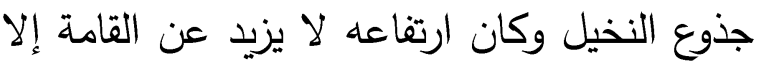

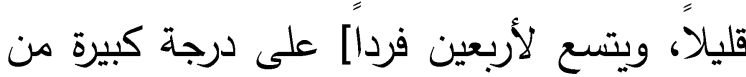
الأهمية في تقوية أواصر التعاون بين المسلمين، ووحدة كلمتهم وتعاونهم على البر والتقوى ' ولم يكن المسجد النبوي منذ إنشائه مجرد دار للعبادة فقط، بل إضافة إلى ذلك مكانا لكل ما يهح المسلمين في حياتهم، ومن ذلك ما يليّاء ا-إيواء ضعفاء وفقراء المهاجرين الرجال العزاب الذين لم يتمكنوا عند هجرتهم من مكة إلى المدينة من الحصول على منازل خاصة بهم. r-إيواء ضعفاء النساء اللاتي أسلمن من أحياء العرب، ولم يجدن مأوى غير المسجد حين قدومهن المدينة.

r- أنه مكان لتعليم المسلمين أمور دينهم.

'السيرة النبويـة العطرة، السيد عبد الفتاح إبراهيم بـلاط، (القـاهرة، الجربسـي للكومبيـوتر والطباعـة والتصـوير : $\cdot\left(y^{2} \cdot 1\right)$

السـيرة النبويسة في ضـويء المصـادر الأصـلية: دراسـة

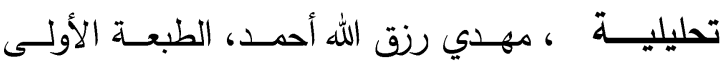
(الريـاض، مركـز الملـك فيصـل للبحــوث والدراســات

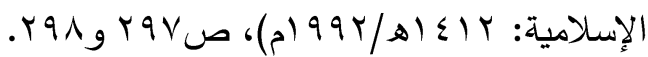

وفتوى وغيرها وينشغلون بالجلوس في الحرم انتظارا للصلاة أو بقراءة القرآن الكريم عن تققد ما بـ يضمه هذا المسجد من كنوز معرفية تساعد على تتمية الوعي الديني ؛بجانب الصلاة والاستماع إلى بعض خطباء المسجد من أصحاب الأصوات النورانية ، حيث يعتبر زائرو المسجد النبوي أن صلاة الفجر في هذا المكان ريح من رياح الجنة تدخل في نفوسهم السكينة والاطمئنان. وحرصا على تعميم فائدة ما يقدمه المسجد النبوي من معرفة دينية عبر وسائل التقنية الحديثة؛ فقد عمدت الباحثه إلى الحصول على مؤشرات من عينة من المصرين العاملين في المملكة العربية السعودية في المدينة المنورة أو المقيمين بها للدراسة أو العمل أو الزيارة أو الحج أو العمرة.. الخ ،وذلك عن مدى معرفتهم واستخداماتهم للوسائل التقنية التي تقدم داخل المسجد النبوي في ظل توسعته التي لم يشهد الزوار لها مثيلا منذ أن قامت الدولة السعودية بعد تأسيسها بهذا الدور بعد أن ظل المسجد بدون أية توسعة من أي نوع على مدى ألف وسعبين عاما حتى انبثاق العصر السعودي وبدء التوسعة الكبرى في العهد الحديث على يد الملك المؤسس عبد العزيز بن عبد الرحمن آل سعود ، وسار أبناؤه الكرام على إكمال هذه التوسعة وتزويد المسجد النبوي بكل جديد في عالم التقنية لراحة زواره بكل ما ييسر للزوار أمورهم: صلاة وتعبدا ونهلا من العلم الثرعي وزيادة معرفتهم الدينية لتتمية الوعي الديني لديهم. 
الشرعي؛ وتخصيص قاعات للرجال وأخرى اللسيدات داخل المكتبة. تزويد المكتبة داخل الحرم النبوي بأمهات الكتب الشرعية وبمراجع نادرة في الفقه والتقسير والعلم الثرعي. - تقديم وعرض شرائط وكتب تتضمن الخطب والدروس التي يلقيها العلماء في

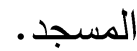
- توزيع مصاحف ووسائل إيضاح متعددة على زوار المكتبة والحرم النبوي لزيادة الوعي الديني والمعرفي. - إقامة ندوات وعقد دورات ومحاضرات

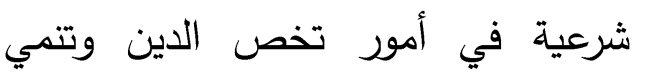
درجة الوعي الديني لدى زوار الحرم. - الأخذ بكل وسائل وسبل جديدة ووسائل لائل إيضاح متاحة وتعريف الزائرين بها،

وتقديم نسخ منها لراغبي اقتنائها. إن ما حدث ويحدث من تقدم وتطور عمراني وتقني في المسجد النبوي إنما يهدف إلى

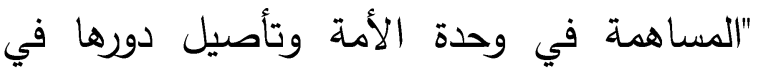

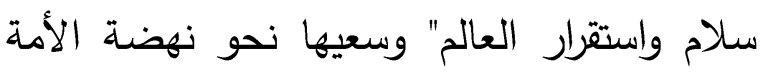

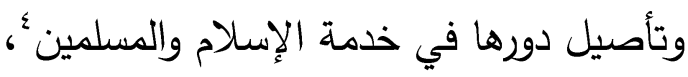
أهمية الدراسة تتمثل في التالي:

كُكلة خادم الحرمين الثربفين الملك سلمان بن عبد العزيز؛ في الاحتفال باليوم الوطني للمملكة نقلا عن: -وكالة الأنباء السعودية (داس).

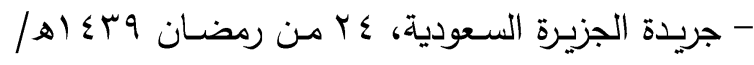

ع- كان مكانا لاجتماع المسلمين بقائدهم

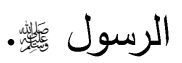

0- كانت تتصب فيه خيمة وقت الحرب لعلاج جرحى المسلمين في الحرب. 1-مكان لاستقبال الرسل - السفراء - الذين

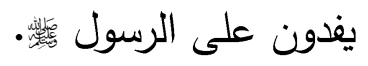
V- كان مكانا لعقد ألوية جيش وسرايا المحاربين دفاعا عن الدين...الخ. لونان.

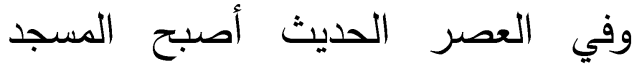
النبوي ليس متسعا لملايين الزوار؛ خاصة في لهاب موسم الحج من كل عام؛ وكان لابد من التوسعة التي قامت بها الدولة السعودية ، في تاريخ المسجدين في الثاني من نوفمبر من عام

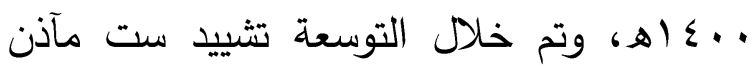
جديدة ارتفاع كل منها مائة متر وخمسة أمتار، كما أضيف للمسجد VY قبة متحركة زنة الواحدة منها ، 1 طنا، وغطيت أرض الحرم والساحات المحيطة به بالرخام العاكس للحراة والجرانيت، وبجانب العران الفخيم للحرم النبوي سارت حكومة المملكة بقيادة أبناء الملك المؤسس وصولاً إلى خادم الحرمين الثريفين جلالة الملك سلمان بن عبد العزيز بتحديث تقني معاصر على أحدث الحثن النظم شمل عدة مساقات داخل الحرم النبوي؛ منها:

- الاهتمام بالأئمة والدعاة من العلماء داخل المسجد. - التوسع في الدكتبة الموجودة داخل الحرم؛ كأقدم وأهم مكتبة متخصصة في العلم

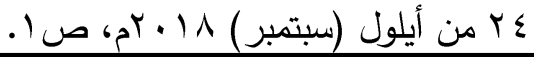


خلال الإفتاء داخل الحرم وذلك من خلال

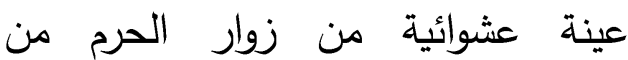
المصريين المقيمين في السعودية، والتعرف على مدى استفادتهم مما يقدم داخل الحرم من تقنيات معاصرة. د- من أهم الاراسات السابقة:

يوضح مسح الدراسات الخاصة بموضوع هذا البحث كثرة الدراسات الإسلامية التي تتناول المسجد النبوي ومكانته وأهميته ؛ مع نقص شديد الإندان في الدراسات التطبيقية والعملية ؛ من هذه الدراسات ما يلي : - - دراسة عالم الاجتماع أحمد أبو زيد بعنوان

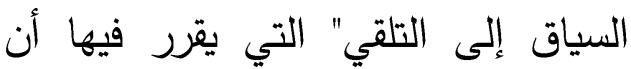
سياق الخطاب الديني يبدأ من الذات لئري المنتجة للخطاب (الخطيب أو الداعية أو الو لان المفتي) مرورا بالخطاب الديني نفسه وصولا إلى الجمهور المتلقي لهذا لهابي الخطاب، حيث ضمن د.أحمد زايد هذه الدراسة ثلاث دراسات تطبيقية؛ • الأولى: عن التعليم الديني في مصر ؛ تُلئه :

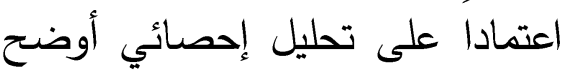
طبيعة التتوع والتعدد في طرائق إلقي التعليم الديني والانتشار الواسع لهذا التعليم، وأطلق الباحثه على انتشار هذا النمط "انتشار المنصات الخطابية

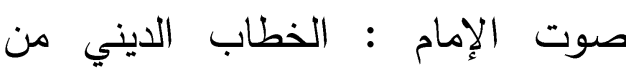

أ. من الناحية النظرية إحياء مكانة المسجد النبوي كأول مسجد "جامع" في الإسلام. ب. من الناحية التطبيقية معرفة مدى استفادة زوار الحرم النبوي من التقنيات الحديثة التي تقدم لهم العلم الثرعي وتساعد في تنمية المعرفة الدينية لديهم.

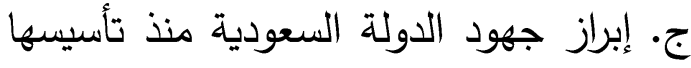
حتى الآن في توسعة وتجديد وتأثيث الحرم النبوي وتزويده بالتقنية الحديثة ليكمل دوره كمشعل إضاءة لاستمرار الحركة العلمية الثرعية التي بدأت منذ لاعناف

$$
\text { ج- أهداف الدراسة: }
$$

تسعى هذه الدراسة بشكل أساسي إلى تحقيق هدفها الرئيسي؛ وهو معرفة آراء زوار المسجد النبوي [الذى يطلق البعض عليه "المسجد الأعظ"] في ما يقدم فيه من وسائل تقنية حديثة تساعد على استمرار نشر دوره العلمي في تتمية الوعي الديني وبخاصة في ظل اهتمام قادة الدولة السعودية بعمارة واستمرار رسالة هذا المسجد النبوي الشريف في خدمة العلم الشرعي.. وتتبثق من ذلك عدة أهداف فرعية للدراسة تتلخص في فلي - التعرف على وسائل وأساليب التقنية الحديثة المتاحة للزائرين داخل الحرم النبوي. - - معرفة آراء زوار الحرم النبوي في ما يقدم ْصوت الإمام: الخطاب الديني من السياق إلى التقلي،

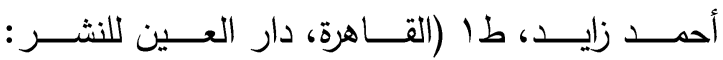
A
داخله لنشر العلم الشرعي والتفقه في

الدين والتبصر بالقضايا الحياتية من 
التلقي.. واستخلصت الباحثه من هذه

$$
\text { الدراسات ما يلي: وانئ }
$$

م أن القيم السياسية في الخطاب:

الديني تتضمن بشكل مباشر أو أو فئر

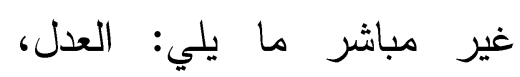

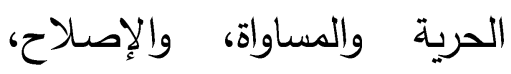

والمسؤولية الاجتماعية،

$$
\text { والمواطنة...الخ. }
$$

م أن عددا من القيم الاجتماعية

تكررت في هذه الخطب، منها:

الاحترام وحسن التعامل، والتكامل

والتعاون، والتسامح، والوفاء

$$
\text { بالعهد...الخ. }
$$

م أن أهم القيم الثخصية في عينة

الخطب تضمنت ما يلي: حسن الخد

الخلق (الدين والخلق)/ الأمانة/

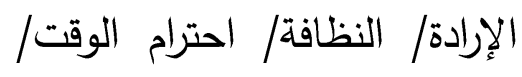

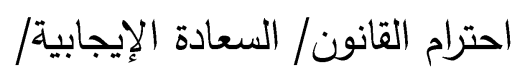

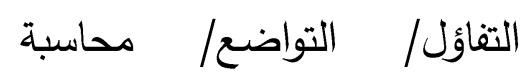

$$
\text { النفس...الخ. }
$$

م أن المشاركين في الاستقصاء

حدوا عدة مواصفات في الداعية

الذى يجذب انتباههم ويؤثر فيهم؛

في مقدمتها ما يلي؛ أن حديثه

يأتي من القلب، وفيه مصداقية،

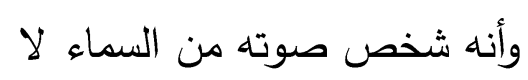

يوجد لله مثيل، ومجتهد، وحديثه

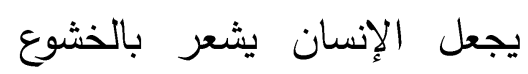

والراحة والثرب من الله، وأن نبرة بالأنسان
وتمددها في حياة الناس، وهدف من هذه الدراسة إلى التعرف على كيفية

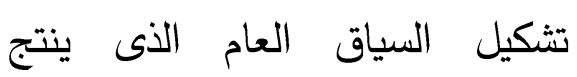
الخطاب الديني في مصر، وأيضاً

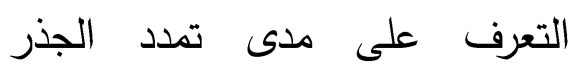

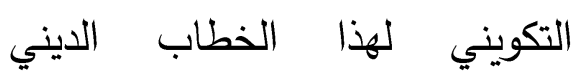

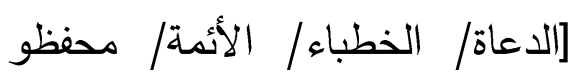

$$
\text { القرآن الكريم...الخ] }
$$

• الثانية: تحليل مضامين عينة من لخدين

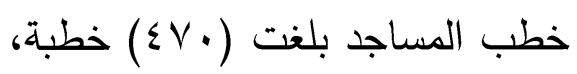

$$
\text { تم استقاؤها من مصدرين: }
$$

أ- خطب ألقاها كبار الدعاة؛ منشورة

في كتب لتكون مرجعاً لخطباء

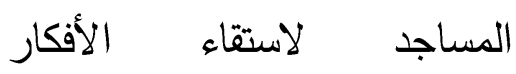

$$
\text { الخطابية (Y) (Y) خطبة). }
$$

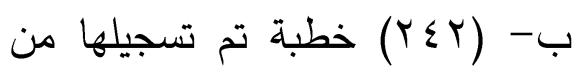

المساجد في مناطق القاهرة

الكبرى، وبنى سويف، والمنيا،

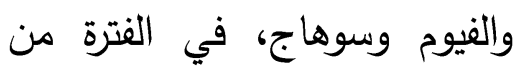

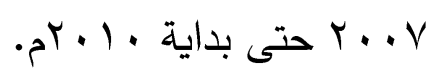

الثالثة: استبيان تم تطبيقه على عينة

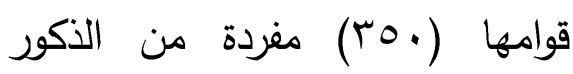

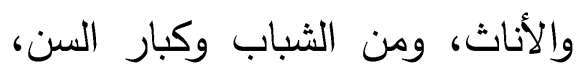
وتم تحليل البيانات التي تضمنها

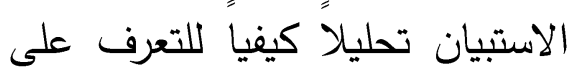
الاتجاهات والميول الدينية والموقف التفاعلي مع صور الخطاب الديني التي يفرزها كبار الدعاة، والتفاعل الإيجابي أو السلبي في عملية 
للتيارات الإسلامية في مصر، وذلك من خلال البرامج الحوارية، حيث أن هذه البرامج التليفزيونية أمدت الجمهور بالمكونات الروحية والفكرية لهذه التيارات الإسلامية، الأمر الذى يعطي الجمهور

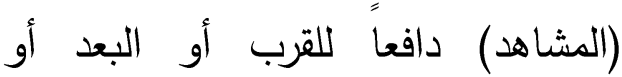
المقاطعة أو المقاومة أو التأييد لهذه التهاه

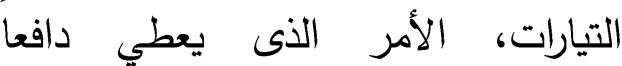
لاستخدام الوسائل التثنية الحديثة في لإني مجالات الإقناع وتغيير الاتجاهات أو لوسيتاتئل تثبيتها وتقويتها.

- مجموعة بحوث عن المواطنة ومستتبل الديمقراطية في مصر، التي تضدنت مجموعة دراسات قدمت للمؤتمر السنوي السابع عشر للبحوث السياسية الذى عقده مركز البحوث والدراسات السياسية بكلية الاقتصاد والعلوم السياسية في جامعة القاهرة ، وضم مجموعة باحثين وضعوا قضية الدين كهوية للمجتمع المسلم تحت مجهر البحث العلمي، وكيف أن المسجد المبلدئ أحد الوسائل المهمة التي تقدم قضايا حياتية للمجتمع تحافظ على تماسكه في ظل الأخوة والمشاركة الوطنية والمواطنة،

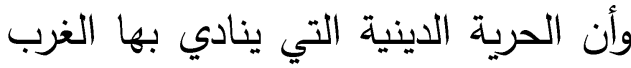

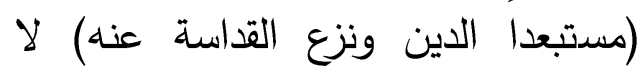
يمكن أن تتم بهذه الصورة في المجتمع المسلم حيث تطبق الدين قولا وعملا، نظرياً وتطبيقياً في مجتمعاتتا باعتبار أن التشريع الإسلامي تشريع سماوي لا يتغير
صوته مؤثرة وطريقة عرضها

عميقة وبسيطة (السهل الممتتع).

وتعد هذه الدراسة أقرب الدراسات إلى الى الى

موضوع البحث نظرا لما تضمنته من

أفكار معاصرة، وأرقام محددة عن الفناع

التعليم الديني والخطب الدينية ومتلقي هذه الخطب.

- دراسة هشام فروم" عن "تجليات الحجاج (محاولات الإقناع) في الخطاب النبوي" واختار الباحثه الحديث النبوي الشريف باعتباره أقدس النصوص الدينية - بعد الترآن الكريم - لدى المسلمين مع التركيز على الأربعين النووية باعتبارها أقرب إلى لى لتريل

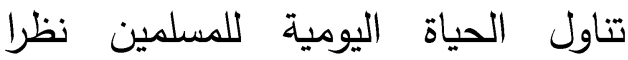
لمعالجتها أهم القضايا الدينية والدنيوية

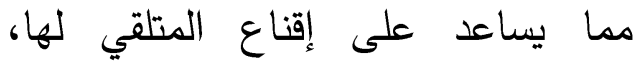

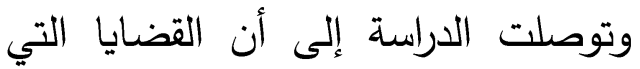
دعا إليها القرآن الكريم والسنة النبوية تمثل الثل الثيات قاسما مشتركا لدى السسلمين بشكل عام. - - دراسة سهام محمد عبد الخالقَ` التي تتاولت اتجاهات الجمهور نحو الدور السياسي

تجليات الحجَاج في الخطاب النوبي: دراسة في وسائل

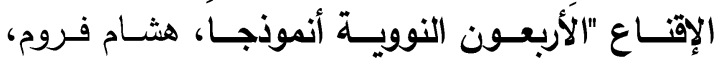

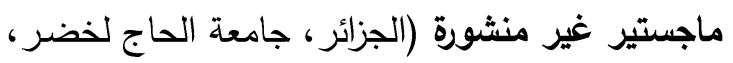
كلية الآداب والعلوم الإنسانية: 9 . + بام). لدور البرامج الحوارية في تثكيل اتجاهات الجمهور الإسانية

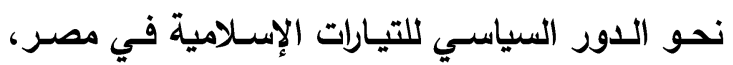

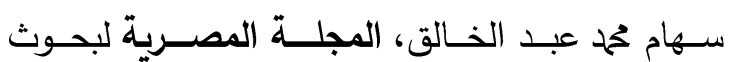
الإعلام، 
العمل وغيرها، وأن يكون الداعية أكثر انفتاحاً وأكثر قدرة على رؤية ناضجة لدور الدين في الحياة بحيث يكون حديث

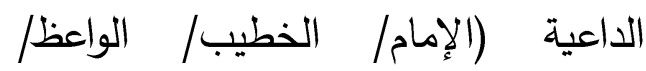
المفتي...الخ) يأتي من القلب وفيه مصداقية كأنه صوت آت من السماء

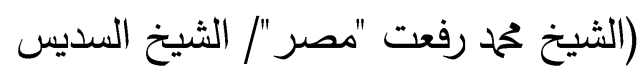

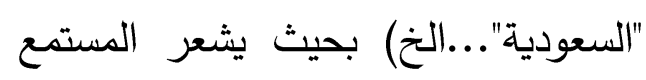
بالراحة والخشوع والقرب من الله.. مع ضرورة الاهتمام بإعداد الدعاة إعدادا جيداً ليكون تعاملهم مع وسائل وأساليب العصر غير منبتة. - مجموعة دراسات عن "الحرية والمواطنة: التتوع والتكامل"(·') قدمت لمؤتمر الأزهر ومجلس حكماء المسلمين؛وأكد العلماء فيها على ضرورة الاهتمام بالمواطنة ووطنية من يضمهم أي بلد سواء كان إسلامياً أم غير إسلامي، فالرسول الكريم  التي طرده أهلها منها ليذهب المدينة المنورة التي استقبلته لتتشر لهرده الدعوة، فقال الرسول الكريم للمشركين في مكنة يوم الفتح: "اذهبوا فأنتم الطلقاء" فالمسجد عندما يتناول أمور المسلمين فإنما يستدعي أول ممارسة إسلامية لنظام الحكم الذى طبقة النبي في في أول مجتمع أسسه، وهو مجتمع المدينة.

هـ - مثكلة الدراسة:
بتغير أشخاص أو ظروف أو مكان أو

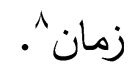

- أبحاث المؤتمر الرابع والعشرين للمجلس الأعلى للثؤون الإسلامية في مصر بعنوان "عظمة الإسلام وأخطاء بعض الإسله

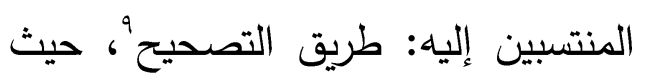
عددت هذه الدراسات مدى عظمة الإسلام في التعامل مع غير المسلمين، ناهية عن توظيف الدين في السياسة ومخاطر ذلك على المجتمع، وأن المسجد في مقدمة الوسائل التي عليها أن تبين أهمية الوطن والمواطنة وتقديم واجبات المواطنة قبل المطالبة بالحقوق؛ أو على الأقل بالتزامن

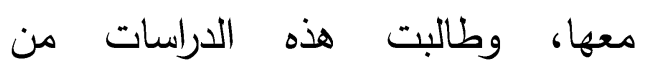
المسلمين أن يكونوا قدوة في تعاملاتهم حتى مع أسرهم الصغيرة مروراً بأماكن

^دور البرامج الحواريـة في تشكيل اتجاهـات الجمهـور

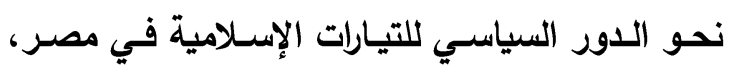

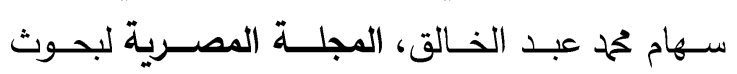
الإعلام،عظمة الإسلام وأخطاء بعض المنتسبين إليه:

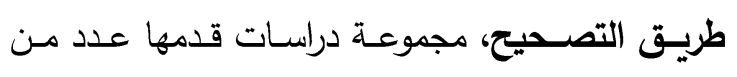

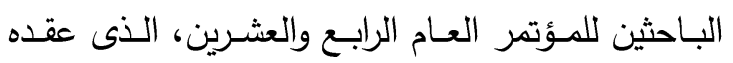

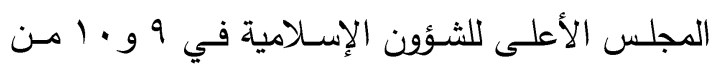

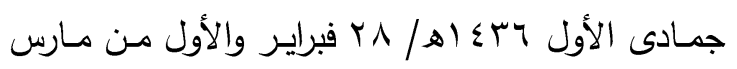
. 10 9 الحريـة والمواطنة: التنوع والتكامل، مجموعة دراسات قدمت إلى مؤتمر الأزهر ومجلس حكماء المسلمين الذى ولى التهاء انعقد في القاهرة في الأول والثاني من جمادى الآخرة

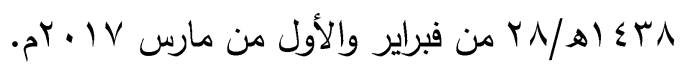


تتمثل مشكلة الدراسة في عدم وجود الكريم وعيد الفطر في بلدانهم وقراهم، وجاء

اختيار هذه العينة لقربها من الحرم النبوي واعتياد أغلبهم الصلاة فيه، وبذلك تكون نتائج الاستطلاع واقعية باعتبارها ممارسة يومية لأداء الصهلاة واكتشاف الوسائل التقنية كمساعدة في نشر الاعوة وتقوية الوازع الديني وتتميته لدى هؤلاء الزائرين (تم توزيع · r ( ) استمارة استبيان على عدد من المصرين العائدين من السعودية لقضاء إجازة عيد الفطر المبارك، وقام بتعبئتها المتعلمون أما غير المتعلمين من المصرين والمصريات المصاحبات لأزواجهن، فقد تمت مساعدتهن من جانب بعض جيرانهن أو معارفهن في تعبئتها، وبلغ عدد الاستمارات الصالحة للتحليل ...

(استمارة)

ز - تساؤلات الدراسة:

تسعى هذه الدراسة للإجابة عن التساؤلات التالية: - ما موقع الحرم النبوي لدى زواره؟ وكيف يرونه في إطار الإسلام وأداء الشعائر

الدينية؟

- ما مدى حرص قاطني المدينة المنورة؛ من غير السعوديين؛ على أداء الصلوات

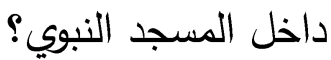
- كيف يرى زائرو المملكة الحرم النبوي بعد إعادة تجديدهوعمارته بهمة قادة وزعماء الدولة السعودية منذ نشأتها حتى عهد خادم الحرمين الشريفين الملك سلمان بن

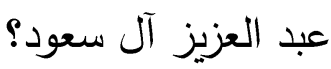

معلومات وإحصاءات دقيقة وصحيحة عن مدى استفادة زوار المسجد النبوي مما توفره حكومة المملكة العربية السعودية وإدارة الحرمين الشريغين من تقنيات متجددة ومتعددة لزوار المسجد، هذه الإمكانات التي تهدف إلى زيادة الوعي الديني لهؤلاء الزوار، واكتفاء بعض الزائرين بالصـلاة وقراءة القرآن الكريم أو الاستماع إليه داخل المسجد، الأمر '1 الذى يعد هدرا لهذه الإمكانات التقنية وتوضح الدراسة الميدانية سبل التغلب على هذه المشكلة بهدف استخدام الطاقات - المادية والمعنوية كافة داخل الحرم من خلال آراء ووجهات نظر تطبيقية وعملية لعينة الدراسة الميدانية. و - مجتمع الدراسة وحدودها الزمانية والمكانية: يتمثل مجتمع الدراسة في زوار المسجد الحرام من غير السعوديين العاملين في المدينة المنورة والمقيمين فيها كمتطلب من متطلبات العمل، وتم اختيار عينة عشوائية من المصريين المقيمين في المدينة المنورة [للعمل، أو الدراسة، أو العلاج، أو الزيارة المطولة r أشهر فأكثر].. وبلغت العينة الصالحة للبحث ( . . ب) مغردة من هؤلاء المصريين خلال عودتهم إلى مصر خلال شهر رمضان وبا اهـ لقضاء بعض أيام الشهر

'علم الاتصـال المعاصر، عبد الله بن مسعود بن تركي الطويرقي، الطبعة الأولى (المملكة العربيـة السعودية،

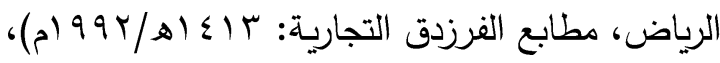


- هل توجد فروق ذات دلالة بين النوع كجزء من اتجاهاتهم نحو إصدارهم للأحكام...الخ،

(ذكر/ أنثى) في رويتهم لمكانة الحرم ومدى معرفته واستفادتهم من التثنيات الموجودة

بالمسجد؛ تم إجراء اختباري الصدق والثبات على

النبوي؟

هذه الاستمارة؛ على النحو التالي (r'):

- - هل هنالك فروق ذات دلالة إحصائية بين

• الإجراء الأول: اختبار الصدق: يقصد

وجهة نظر المصريين من سكان المدينة

Validity الصدق أو الصحة

صلاحية الاستمارة المعدة للجانب

تختلف عن وجهة نظر أقرانهم المصريين

من سكان الأرياف تجاه الحرم النبوي؟

الميداني لهذه الدراسة لقياس الثئ

المراد قياسه بأكبر دقة ممكنة [رؤية

المصرين وانطباعاتهم عن وسائل

وأساليب التقنية الحديثة في الحرم

النبوي] وذلك بهدف ارتفاع مستوى

الثقة في النتائج، وقد روعي في

تصميمها تمثيل هذا الاختبار لنواحي

الجانب التطبيقي في الدراسة، وكذلك

- - هل هنالك من يعتقد حتى الأن بأن زيارة

المسجد النبوي يمثل الحج أو أحد أركانه؟ لهاب

- ما مدى زيارة المصريين المقيمين في

"المدينة المنورة" للحرم النبوي؟ وما مدى

استفادتهم من الوسائل والسبل التي توفرها

إدارة الحرم لزيادة وتعميق الوعي الديني

لاى هؤلاء الزوار؟

ح- إجراءات الصدق والثبات:

صدق التوافق Concurrent Validity

بعد إعداد الباحثه لاستمارة الاستبيان

Construct وصدق البناء

متضمنة مجموعة أسئلة عن أهمية المسجد النبوي

م.....الخ وقد تم اختبار قبلي

على عينة من المبحوثين وصلت

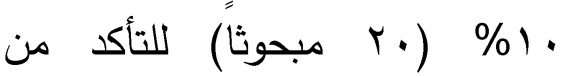

وضوح أسئلة استمارة الاستبيان وأنها

ومدى تكرار زيارة المصريين المقيمين في "المدينة

المنورة" للمسجد في أوقات الصلاة وفي غيرها

والصورة الذهنية Image والصور النمطية

Stereotypes

تقيس مدى معرفة واستخدام

المبحوثين (عينة الدراسة) لوسائل معري

التقنية الحديثة داخل المسجد النبوي

"راجع في هذه النقطة البحثية:

ومدى استفادتهم منها، ثم توزيعها

على مجموعة لخبراء

-بحـوث الإعــلام: الأسـس والمبــادئ، ســير حسـين

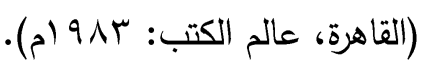

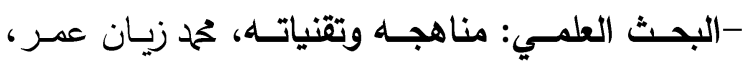

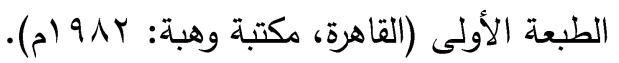

-الصـدق والثبـات في اســمارتي الاستقصـاء وتحليـل

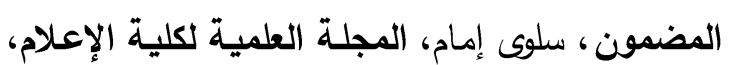

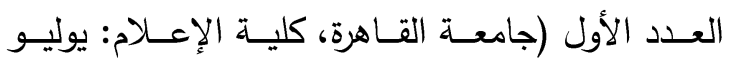
. (م) $9 \wedge 9$

- تحليـل المحتوى في بحـوث الإعـلام، خحمد عبد الحميد

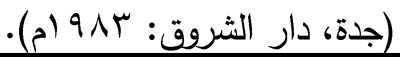


التوزيع على الـ/1\% من العينة في المرة الثانية بعد مرور 10 يوما من تعبئتهم الاستمارة في المرة الأولى حتى لا يكونوا متذكرين إجاباتهم السابقة، وقبل مرور • ب يوماً من إجاباتهم الأولى تحسباً لاكتساب بعضهم خبرات جديدة كزيارة الحرم

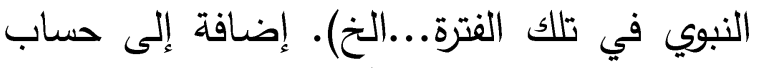
معامل الثبات - أيضا- عن طريق معادلة هولستي الخاصة بتحديد الثبات عن طريق نسبة الاتفاق بين "المرمزين" أو "المصنفين" للاستثمارات

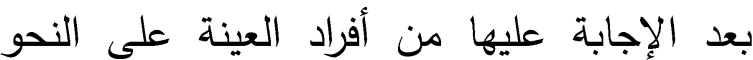
التالي: - - التي:

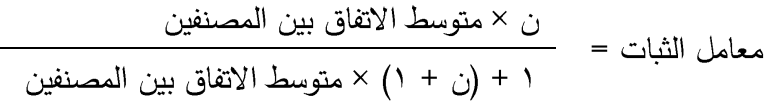

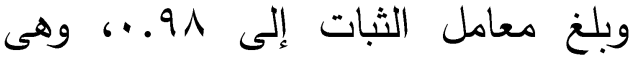
نسبة ممتازة تعني - تقريبا- ثبات آراء

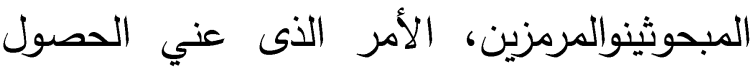

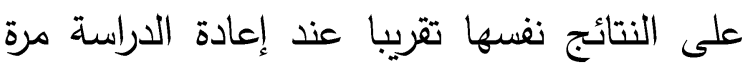
أخرى بالمعطيات والظروف نفسها. ط- المعالجة الإحصائية للآراء بعد (تكميمها) والمعلومات والبيانات:

في الدراسة الميدانية تم الاعتماد على (Y..)

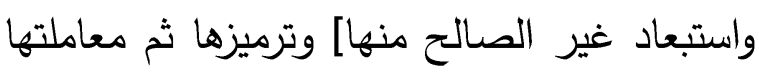
إحصائيا عن طريق الحاسب الآلي، ومعالجتها واستخراج النتائج الإحصائية باستخدام برنامج SPSS Statistical Package for the Social Sciences واستخدام المعالجات الإحصائية المتقدمة من تكرارات بسيطة ومركبة ونسبة مئوية، واختبارات

$$
\text { متعددة أخرى. }
$$

والاختصاصيين الإعلاميين ممن

سبق لهم زيارة المسجد النبوي (خلال

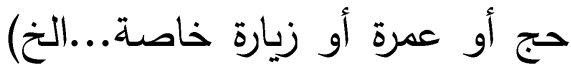
للتأكد من قدرة الاستمارة على قياس الأمر المراد قياسه وتم الاسترشاد الادئا ببعض الآراء المفيدة وإضافة أو الو الأل تعديل بعض أسئلتهاج" بناء على آراء الخبراء والاختصاصيين. • الإجراء الثاني: اختبار الثبات: الثبات هنا يعني أنه عند إعادة الاختبار مرة الإناء أخرى وفي الظروف نفسها تكون النتائج متسقة، أي الحصول - تقريبا - على النتائج نفسها الذى سبق الحصول عليها من قبل.. أي لو كررنا الإجراءات نفسها لحصلنا على نتائج متسقة توذات ثقة ،Accuracy ودقة Dependability وهذا كله من أجل تقليل الخطأ في النتيجة المستخلصة من البحث. وبعد توزيع استمارة الاستقصاء على أفراد العينة عمدت الباحثه إلى إعادة اختبار الثبات بتوزيع (†.T) استمارة استقصاء مرة أخرى على الفى

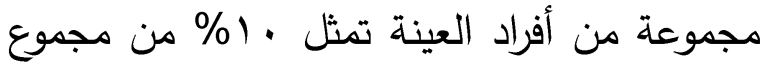
عينة البحث وذلك لمعرفة نسبة الثبات في

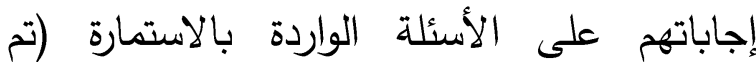

Mass Communication Theories and research, Grid Publishing, Columbus O: 1981. 
لهؤلاء المتلقين وعنصر المصداقية لديه والأسلوب

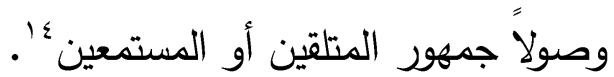

\section{ثانياً: الجاذب العملى :}

قامت الباحثة باختيار عينة من المصرين

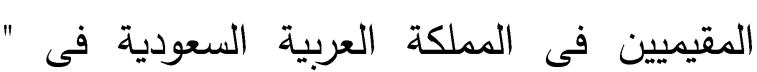
المدينة المنورة " خلال قضائهم شهر رمضان وعيد الفطر المبارك فى مصر " ، وتم توزيع الاستبانة على العينة المختارة ، تم استخدام الصالح منها ( . . . استمارة ) والتعامل معها إحصائيا وتحليليا لاستخراج النتائج واستخراج

الدلالات وكانت كما يلى :

خصائص عينة الدراسة :

جدول (1) يوضح وصف عينة الدراسة

\begin{tabular}{|c|c|c|c|}
\hline \multicolumn{2}{|c|}{ إجمالي } & & \multirow{2}{*}{ المتفيرات } \\
\hline$\%$ & ك & & \\
\hline 0 . & $1 \ldots$ & ذكور & \multirow{3}{*}{ النوع } \\
\hline 0 . & $1 \ldots$ & إناث & \\
\hline $1 \ldots$ & r.. & جملة & \\
\hline YI & $\leqslant r$ & اقل من • r سنة & \multirow{5}{*}{ العمرية } \\
\hline rA & 07 & من •r - لأقل من •r سنة & \\
\hline YV.O & 00 & من •r - لأقل من •0 سنة & \\
\hline$r$ r.o & $\varepsilon V$ & من •• سنة فاكثر & \\
\hline $1 \ldots$ & $r \ldots$ & جملة & \\
\hline$r$. & 7. & اقل من متوسط & المؤهل \\
\hline
\end{tabular}

' ' منظومة القيم: سياسـات استعادة التوازن في مراحل مـا بعـد الثـورات، محمد محمود السـيد، مجلـة "مفــاهيم المسـتقبل"، العـدد "Y" فبرايـر 10 • بام (القـاهرة، مركز

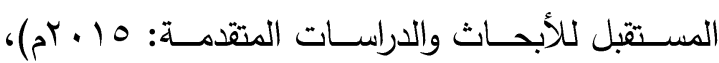
ص ص صا.
ي- نظرية التهيئة المعرفية ومنظومة القيم التي تنطلق منها الدراسة: تنطلق هذه الدراسة من نظرية التهيئة المعرفية Cognitive Priming Theory التي ترجع جذورها إلى نظرية ترتيب أولويات الاهتمام Agenda Setting Theory التبادلية بين وسائل الإعلام والجمهور، ولها جذورها - أيضاً - في نظرية التعلم الاجتماعي...الخ، وأهم مفاهيم هذه النظرية تتمثل في عدة عناصر؛ هى: الإتاحة Availability Reflection وإمكانية الاسترجاع ومفهوم الانعكاس والقضايا المسيطرة والمثيرة للاهتمام، وذلك في إطار من منظومة القيم المجتمعية المستقرة في المملكة، والاستقرار المجتمي، وتقديم القدوة، والمصداقية، والاتساق (ضمان عدم التضارب بين الرسائل المتعلقة بقضايا الإصلاح في البلاد)" وهذا كله بغية التغير المعرفي لزوار الحرم النبوي ليكون هذا التغيير في الاتجاه الإسلامي الصحيح وزيادة المعارف التي تتبت المعارف الجديدة الصحيحة لدى الزوار، ويحدث هذا التغير المعرفي نتيجة عدة عناصر مهمة في مقدمتها: قارئ القرآن الكريم،والخطيب ،والمفسَّر ،والمفتي والثارح الذى يعد عنصراً أساسياً في إقناع المتلقين لرسالته، إضافة إلى الخلفية المعرفية

13 Joseph Dominick, The Dynamics of mass communication Reading (New York, Addison - Wesley: 1983. 
من حيث العمل: نسبة بr\% من أفراد العينة

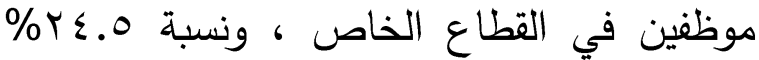
منهج يعملون عامل عادى غير مستديم ، ونسبة

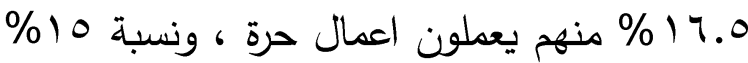
منهم يعملون حارس ( عقارات / شركات /

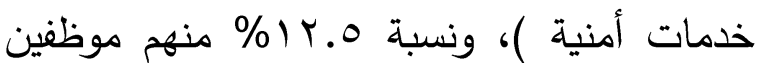
حكوميين، ونسبة 0.0\% منهم لا يعملون على

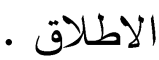
من حيث العمل بالسعودية: نسبة 0§\% من أفراد العينة يعملون في القطاع الخاص ، ونسبة \% \% منهم يعملون عمل موسمى ( خلال الحج

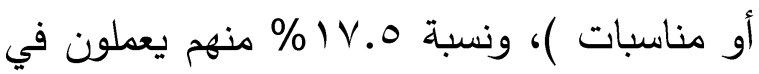

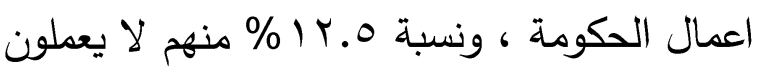

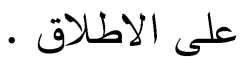

\section{المعالجة الإحصائية للبيانات:}

بعد الانتهاء من جمع بيانات الدراسة

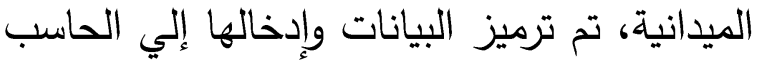
الآلي ، ثم معالجتها وتحليلها واستخراج النتائج الإحصائية باستخدام برنامج "الحزمة الإحصائية Statistical Package " SPSS للعلوم الاجتماعية for the Social Science " وتم اللجوء إلى المعاملات والاختبارات الإحصائية التالية في تحليل بيانات الدراسة : - التكرارات البسيطة والنسب المئوية . - المتوسطات الحسابية والانحرافات المعيارية . - معامل ارتباط بيرسون للعلاقة الخطية بين

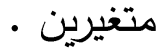

\begin{tabular}{|c|c|c|c|}
\hline$r$. & 7. & تعليم متوسط & \\
\hline rY & $T \varepsilon$ & تعليم جامعي & \\
\hline$\wedge$ & 17 & دراسات عليا & \\
\hline $1 \ldots$ & $r .$. & جملة & \\
\hline 0.0 & 11 & لا عمل لي على الاطلاق & \\
\hline$r \leqslant .0$ & $\leqslant 9$ & عامل عادى غير مستديم & \\
\hline 10 & $r$. & 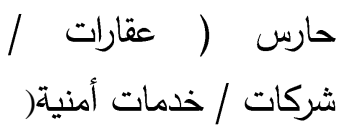 & \\
\hline 14.0 & ro & موظف حكومى & \\
\hline ז & or & موظف فى القطاع الخاص & \\
\hline 17.0 & rT & أعمال حرة & \\
\hline $1 \ldots$ & r.. & جملة & \\
\hline 15.0 & ro & لا تعمل & \\
\hline$\leqslant 0$ & 9. & أعمل فى القطاع الخاص & \\
\hline IV.o & ro & فى أعمال حكومية & العمل \\
\hline ro & 0. & عمل موسمى ( الدج مناسبات ) & بالسعودية \\
\hline $1 \ldots$ & $r .$. & جملة & \\
\hline
\end{tabular}
من حيث النوع: نسبة ،0\% من أفراد العينة ذكور ونسبة . 0\% منهم إناث. من حيث العن: نسبة بك^\% من أفراد العينة

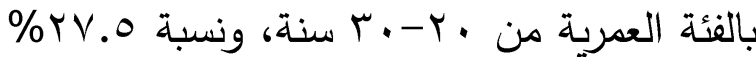
منهم بالفئة العمرية من •r-.0 سنة، ونسبة

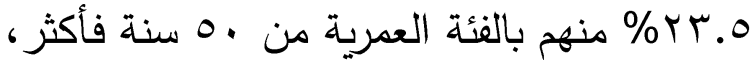

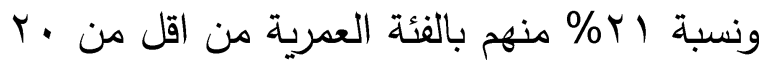

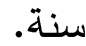
من حيث المؤهل الدراسي: نسبة rب\% من أفراد العينة تعليمجامعي ، ونسبة ·r\% منهم تعليم متوسط، ونسبة ·r\% منهم تعليم متوسط فاقل، ونسبة 11\% م منهم تعليم دراسات عليا. 
مدى زيارة المسجد الثبوى من قبل

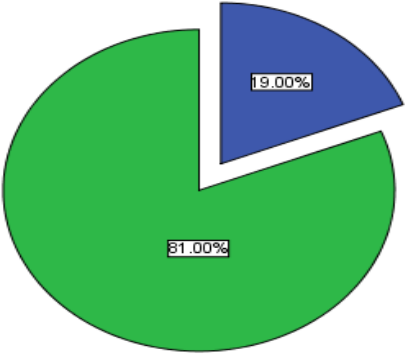

يتضح من الجدول السابق أن نسبة الهر

من أفراد العينة زاروا الحرم النبوي الثريف خلال إقامتهم فى المملكة، ونسبة 9 1\% منهح لم يزوروه من قبل بعضهم ذكر إنها يعمل فى مزارع خارج

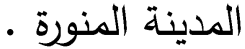

ويتضح وجود فروق في مدى زيارة

المسجد النبوى ، حيث كانت قيمة كاب

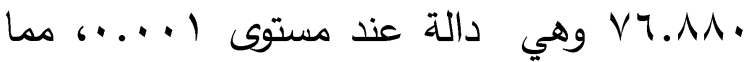
يعني ارتفاع عدد أفراد العينة الذين زاروا الحرم النبوي الثريف من قبل ، ورغم ارتقاع عدد زوار المسجد النبوى الثريف من خلال العينة ، إلا أن نسبة غير الزائرين له مقلقة بالنسبة لهم ويتمنون التمتع بهذه الزيارة وتكرارها . r - عدد مرات زيارة المسجد النبوي: جدول (r) يوضح عدد مرات زيارة المسجد

\begin{tabular}{|c|c|c|c|c|}
\hline \multicolumn{5}{|c|}{ النبوي } \\
\hline \multirow{2}{*}{ الد الدلاية } & \multirow{2}{*}{ كاr } & \multicolumn{2}{|c|}{ الإجمالي } & \multirow{2}{*}{ المسجد النبوي مرات زيارة } \\
\hline & & $\%$ & ك & \\
\hline \multirow{3}{*}{$\cdots \cdots$} & \multirow{3}{*}{$\begin{array}{r}19.9 \\
\text { vo }\end{array}$} & $1 . .0$ & IV & مرة واحدة \\
\hline & & $r \cdot . r$ & $\varepsilon 9$ & مرتين \\
\hline & & r.r & 0\{ & ثلاث مرات \\
\hline
\end{tabular}
- اختبار كاr ( Chi Square Test ) لدراسة مستوى الدلالة الإحصائية للعلاقة بين متغيرين من المتغيرات الاسمية ( Nominal ) - اختبار ( T- Test ) لدراسة مستوى الدلالة الإحصائية للفروق بين المتوسطات الحسابية لمجموعتين من المبحوثين في احد متغيرات الفئة أو النسبة ( Interval Or Ratio) One ) - تحليل التباين ذي البعد الواحد ( Analysis of Variance باسم ANOVA لدراسة مستوى الدلالة الإحصائية للفروق بين المتوسطات الحسابية لأكثر من مجموعتين من المبحوثين في احد متغيرات الفئة أو النسبة ( Interval Or Ratio) - الاختبارات البعدية ( Post Hoc Tests ) بطريقة اقل فرق معنوي ( Least Significance 10) والمعروف اختصارا باسم (Difference) لمعرفة مصدر التباين وإجراء المقارنات الثنائية بين المجموعات التي يشبت ANOVA وجود فروق دالة إحصائيا بينها . ا - مدى زبارة المسجد النبوى من قبل: جدول (Y) يوضح مدى زيارة المسجد النبوى خلال الإقامة في المدينة

\begin{tabular}{|c|c|c|c|c|}
\hline \multirow{2}{*}{ دستوى الدلالة } & \multirow{2}{*}{ كاץ } & \multicolumn{2}{|c|}{ الإجمالي } & مدى زيارة \\
\hline & & $\%$ & كs & من قبل " \\
\hline & \multirow{2}{*}{$\vee ५ . \wedge \Lambda$. } & (1) & 174 & نعم \\
\hline & & 19 & $r_{\Lambda}$ & $y$ \\
\hline
\end{tabular}

•'علم الاتصـال المعاصر، عبد الله الطويرقي، مرجـع

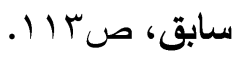




\begin{tabular}{|c|c|c|c|c|}
\hline \multirow[b]{2}{*}{ الدلاية } & \multirow[b]{2}{*}{ كاr } & \multicolumn{2}{|c|}{ الإجمالي } & مدى الارتباط الزيـارة \\
\hline & & $\%$ & ك & 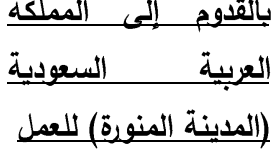 \\
\hline \multirow{3}{*}{$\cdots \cdots$} & \multirow{3}{*}{$\begin{array}{l}r \cdot \\
r \leqslant v\end{array}$} & $\vee 1.7$ & 117 & نعم \\
\hline & & YA.乏 & $\leqslant 7$ & y \\
\hline & & $1 \ldots$ & 174 & جملة \\
\hline
\end{tabular}

مدى الارتباط الزيارة بالقدوم إلى المملكة العربية السعودية (المدينة المنودة) للعمل

照

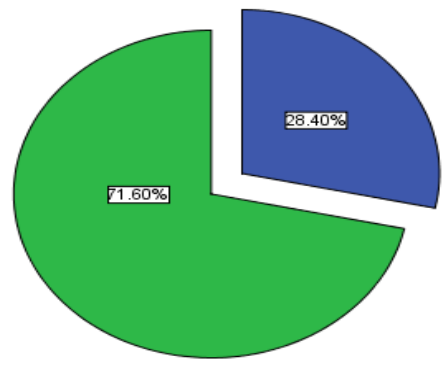

يتضح من الجدول السابق أن نسبة

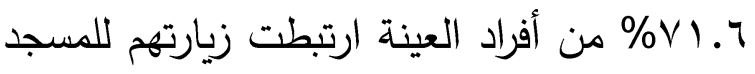

النبوي بالقدوم إلى المملكة العربية السعودية

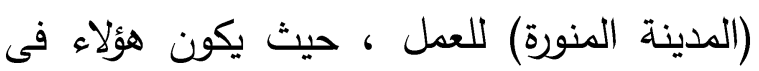

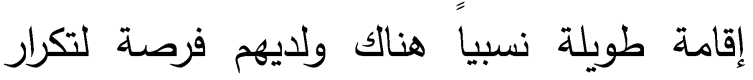

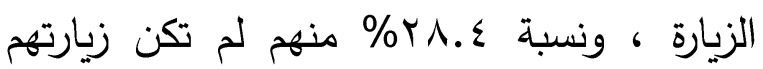
للمسجد النبوي مرتبطة بقدومه للعمل بالمملكة

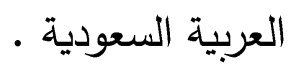

ويتضح وجود فروق في مدى الارتباط الزيارة بالقدوم إلى المملكة العربية السعودية

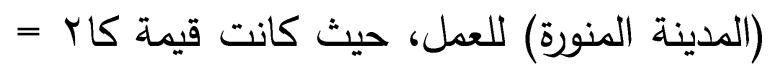
r.r.Y العينة

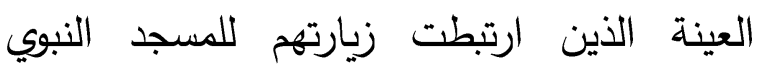
بالقدوم إلى المملكة العربية السعودية (المدينة

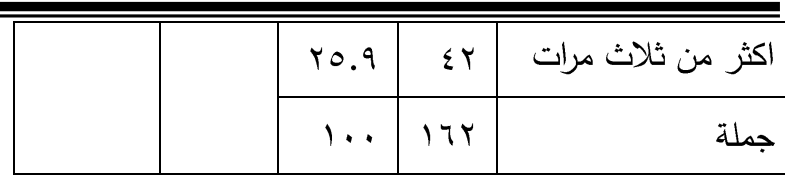

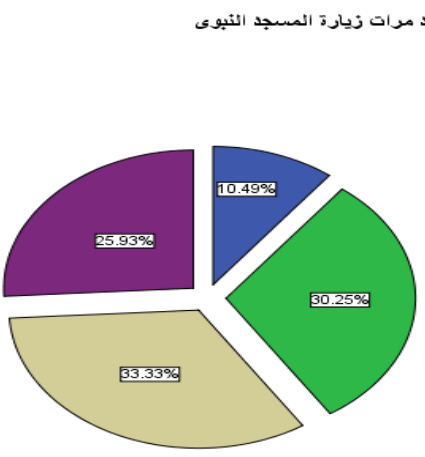

يتضح من الجدول السابق أن نسبة r.rr\% من أفراد العينة زاروالالمسجد النبوي ثلاث

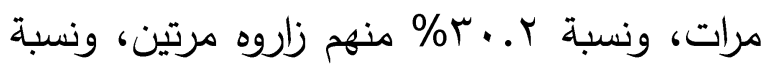

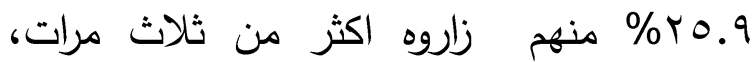

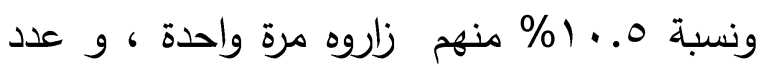

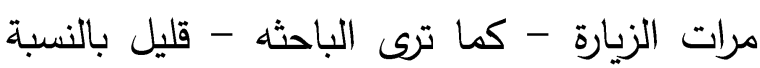

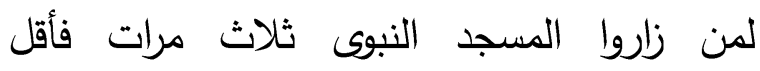

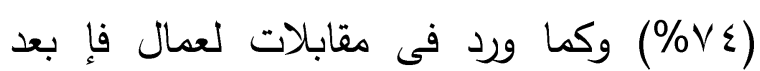
العمل والالتزام بضوابطه تمثلان عائقا لتكرار

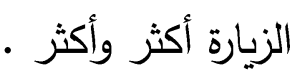

ويتضح وجود فروق في عدد مرات زيارة

المسجد النبوي ، حيث كانت قيمة كاب

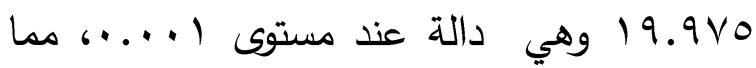
يعني ارتفاع عدد أفراد العينة الذين زاروا المسجد النبوي الثريف أكثر من مرتين بنسبة 90\%. r- مدى الارتباط الزيارة بالقدوم إلى المملكة

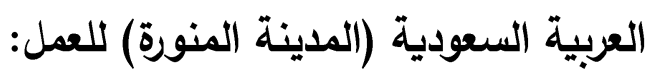
جدول (؛) يوضح مدى الارتباط الزيارة بالقدوم إلى المملكة العربية السعودية (المدينة المنورة) للعمل

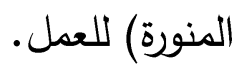


يتضح من الجدول السابق أن نسبة

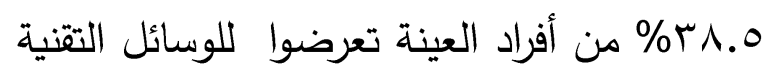

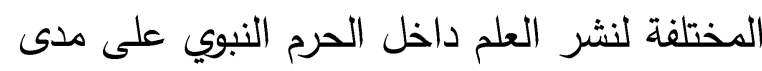

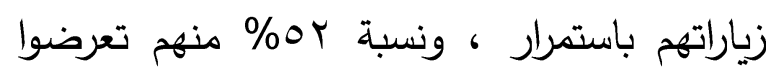

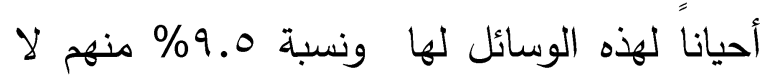

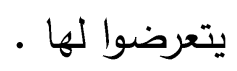

ويتضح وجود فروق في مدى التعرض لئل

للوسائل التقنية المختلفة لنشر العلم داخل الحرم في فئرى

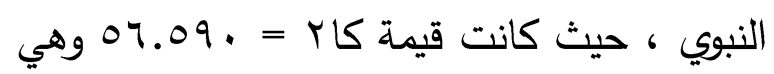

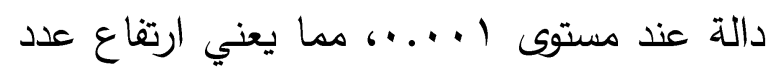

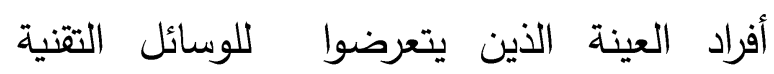
المختلفة لنشر العلم داخل الحرم النبوي.

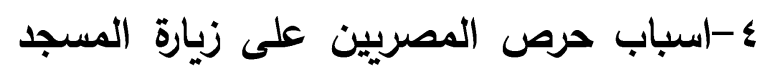
النبوى والصلاة داخله: r- مدى التعرض للوسائل التقنية المختلفة لنشر العلم داخل المسجد النبوي: جدول (•) يوضح مدى التعرض للوسائل التقنية المختلفة لنشر العلم داخل الحرم النبوي

\begin{tabular}{|c|c|c|c|c|}
\hline \multirow{3}{*}{ الد الالة } & \multirow{3}{*}{ SL } & \multicolumn{2}{|c|}{ الإجمالي } & مدى التعرض \\
\hline & & \multirow[b]{2}{*}{$\%$} & \multirow[b]{2}{*}{ ك } & المختلفة لنشر \\
\hline & & & & المسجد النبوي \\
\hline \multirow{4}{*}{$\cdots \cdots$} & \multirow{4}{*}{07.09.} & rᄉ.o & VV & نعم \\
\hline & & or & $1 \cdot \varepsilon$ & أحيانا \\
\hline & & 9.0 & 19 & ע \\
\hline & & $1 \ldots$ & r... & جملة \\
\hline
\end{tabular}

مدى التعرض للوسائل التقنية المختلة لنثر العلم داخل الحرم النبوي 培

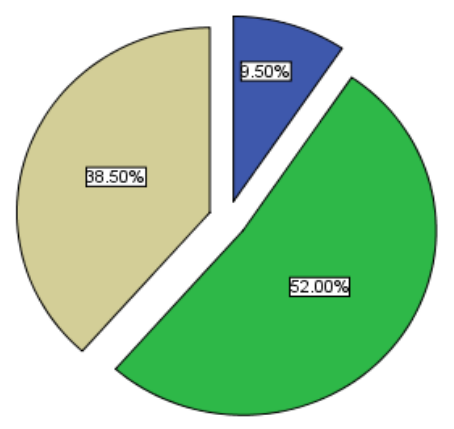

جدول (؟) يوضح أهم اسباب حرص الدصريين على زيارة المسجد النبوى والصلاة داخله 


\begin{tabular}{|c|c|c|c|c|c|}
\hline \multirow{2}{*}{ د مستوى الدلالة } & \multirow[t]{2}{*}{ كاY } & \multirow[t]{2}{*}{ ترتيب } & \multicolumn{2}{|c|}{ ن الإجمالي } & \multirow{2}{*}{ المبسب ابل حرص المصريين على زيارة } \\
\hline & & & $\%$ & 5) & \\
\hline 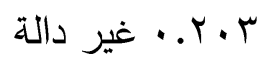 & $1 . T Y$. & r & $0 \leqslant .0$ & 1.9 & لأنه أول مسجد بنى فى الاسلام • \\
\hline. .0 & ᄀ.รᄉ. & 7 & $\varepsilon 1$ & Ar & 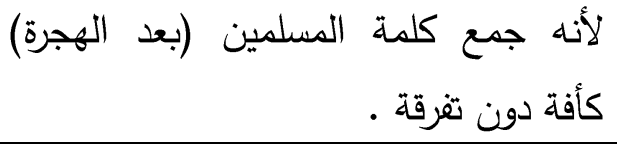 \\
\hline$\cdots 1$ & 9.71. & r & 71 & Irr & زيارة الروضة الشريفة وقبر الرسول (ص) \\
\hline 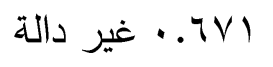 & .17 & $\varepsilon$ & $\sum \wedge .0$ & १V & الراحة النفسية خلال الزيارة . \\
\hline 1هr . • غير دالة & $1 . r \wedge$. & 0 & $\varepsilon \uparrow$ & 94 & ألداء الصلوات خلال الزيارة خاصة صلاة \\
\hline$\cdots \cdots$ & rT.IT. & V & r & 77 & صوت إمام المسجد يجذبنى كأنه من ريح \\
\hline$\cdots \cdots$ & ro.9r. & 1 & 71 & ב & لأنه أحد ثلاثة مساجد تثد الرحال إليها . \\
\hline
\end{tabular}

يتضح من الجدول السابق أن نسبة \%^\% \% ميث كانت قيم كاץ غير دلالة عند مستوى

من أفراد العينة المصريين حرصوا على زيارة . . . المسجد النبوى والصلاة داخلهلأنه أحد ثلاثة - مدى الحرص على البقاء فى المسجد النبوي

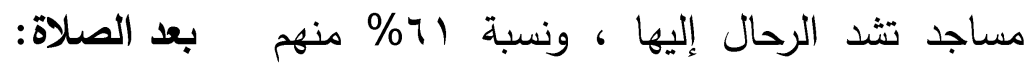
حرصوا على زيارته لزيارة الروضة الشريفة وقبر جدول (V) يوضح مدى الحرص على البقاء فى ل المسجد النبوي بعد الصلاة

\begin{tabular}{|c|c|c|c|c|}
\hline \multirow{2}{*}{ الدلالة } & \multirow[b]{2}{*}{ كاr } & \multicolumn{2}{|c|}{ الإجمالي } & \multirow{2}{*}{ على المسلى البقاء فن المرص } \\
\hline & & $\%$ & ك & \\
\hline \multirow{4}{*}{$\ldots \cdots$} & \multirow{4}{*}{$1 \wedge . \leqslant \psi}$. & $\leqslant V .0$ & 90 & نعم \\
\hline & & YA & 07 & كل عل علب \\
\hline & & $r \varepsilon .0$ & $\leqslant 9$ & ע \\
\hline & & $1 \ldots$ & r... & جملة \\
\hline
\end{tabular}
الرسول (ص)، ونسبة 0ــ\% منهم حرصوا على زيارته لأنه أول مسجد بنى فى الاسلام،

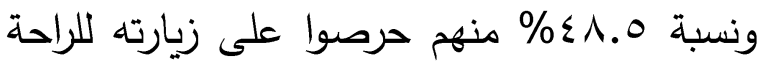

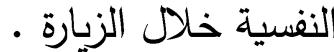

ويتضح وجود فروق في اسباب حرص المصرين العاملين فى المدينة المنورة على زيارة المسجد النبوى والصرلاة داخله، حيث كانت قيم كاب دالة عند مستوى دلالة اقل من ه....، فيما عدا لأنه أول مسجد بنى فى الاسلام و الراحة النفسية خلال الزيارة وأداء الصلوات خلال الزيارة خاصة صلاة الفجر لم يكن بين افراد العينة فروق 
جدول (^) يوضح عدد الساعات التي تقضيها فى المسجد النبوي يومياً خلال زيارتك للمدينة

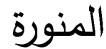

\begin{tabular}{|c|c|c|c|c|}
\hline \multirow{2}{*}{ دلد الدلالة } & \multirow[b]{2}{*}{ كاץ } & \multicolumn{2}{|c|}{ الإجمالي } & عدد الساعات التي تقضيها \\
\hline & & $\%$ & ك5 & خلال زيارتك للمديند النبوي يوميا \\
\hline \multirow{4}{*}{$\ldots 1$} & \multirow{4}{*}{1.94.} & r. & «o & ساعة تقريبًا \\
\hline & & $\varepsilon . .0$ & 11 & من ثلاث ساعات ساعة إلى أقل \\
\hline & & rv & $V \varepsilon$ & أكثر من ثلاث ساعات يومياً \\
\hline & & $1 \ldots$ & $r \ldots$ & جملة \\
\hline
\end{tabular}

عدد الساعات التي تقضيها في المسجد يومياً خلال زيارتك للمدينة المنورة

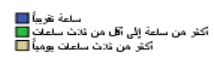

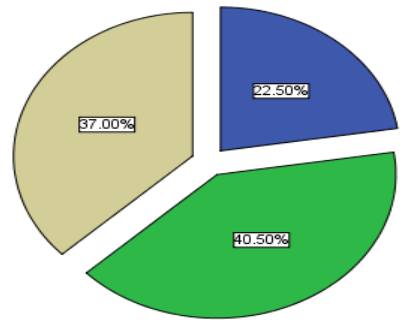

يتضح من الجدول السابق أن نسبة

0. • ـ من أفراد العينة قضوا فى المسجد يومياً

خلال زيارتهم للمدينة المنورة من ساعة الى ثلاث

ساعات، ونسبة \%rV\% منهم يمكث اكثر من ثلاث

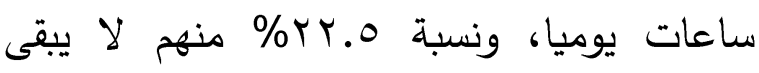
داخل المسجد سوى ساعة تقريا في اليوم. ويتضح وجود فروق في مدى الحرص على البقاء فى المسجد النبوي بعد الصلاة، حيث كانت قيمة كاr = .ب . . 1 وهي دالة عند مستوى (..... مما يعني ارتفاع عدد أفراد العينة الذين يقضوا فى المسجد النبوي يومياً خلال زيارتهم للمدينة المنورة من ساعة الى ثلاث ساعات . V-الاشياء التي تجذب المصريين لتكرار زيارتهم للمسجد النبوي والصلاة داخله:
مدى الحرص على البقاء في المسجد بعد الصلاة

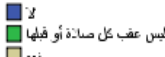

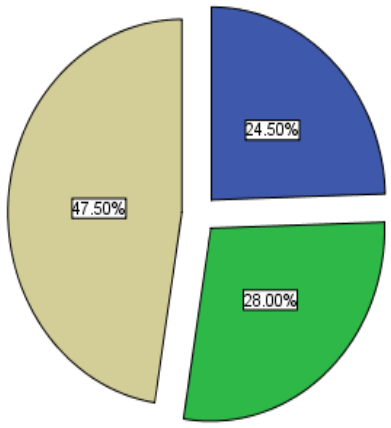

يتضح من الجدول السابق أن نسبة \% \& من من أفراد العينة يحرصوا على البقاء فى المسجد النبوي بعد الصلاة ، ونسبة ^r\% منهم يحرصوا على البقاء فى المسجد ليس عقب كل

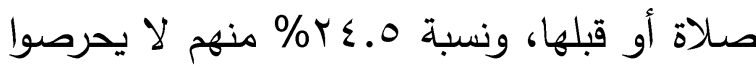
على البقاء فى المسجد.

ويتضح وجود فروق في مدى الحرص

على البقاء فى المسجد النبوي بعد الصلاة، حيث

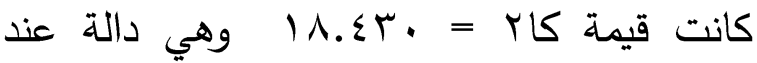
مستوى | (..... مما يعني ارتفاع عدد أفراد العينة الذين يحرصوا على البقاء فى المسجد النبوي بعد الصـلاة. צ- عدد الساعات التي تقضيها فى المسجد التبوي يوميا خلال زيارتك للمدينة المنورة: 
جدول (9) يوضح الاثياء التي تجذب المصريين لتكرار زيارتهم للمسجد النبوي والصلاة داخله

\begin{tabular}{|c|c|c|c|c|c|}
\hline \multirow{2}{*}{ د مستوى الدلالة } & \multirow[t]{2}{*}{ كاr } & \multirow[t]{2}{*}{ ترتيب } & \multicolumn{2}{|c|}{ الإجمالي } & الاشياء التي تجذب المصرين لتكرار \\
\hline & & & $\%$ & ك5 & زبـارتهملمسجد النبوي والصـلاة داخله \\
\hline$\cdots \cdots$ & r^.VY. & 1 & VY & $1 \leqslant \varepsilon$ & حب رسول الله والتشرف بالسلام عليه \\
\hline •^^ء. . غير دالة &. $.0 \ldots$ & $\varepsilon$ & $\varepsilon \vee .0$ & 90 & 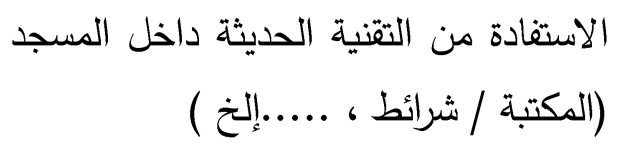 \\
\hline ^هr . • غير دالة & $1 . r \wedge$. & r & o & $1 \cdot 1$ & زيارة المسجد الرسول (ص) التى تحث على \\
\hline. .0 & $0 . \vee \wedge$. & 0 & $\varepsilon 1.0$ & ᄉr & بشكل لا ينقطع الحديثة للمسجد النبوى والمتجدة \\
\hline$\cdots \cdots$ & YI.VA. & r & 77.0 & rזו & النبروس الدينية التى يلقيها خطيب المسجد \\
\hline
\end{tabular}

يتضح من الجدول السابق أن نسبة \%Y\% ....إلخ ) و أحاديث الرسول (ص) التى تحث من أفراد العينة المصريين يجذبهم لتكرار زيارتهم على زيارة المسجد لم يكن بين افراد العينة فروق للمسجد النبوي والصلاة داخله والصلاة داخله حب حيث كانت قيم كاب غير دلالة عند مستوى

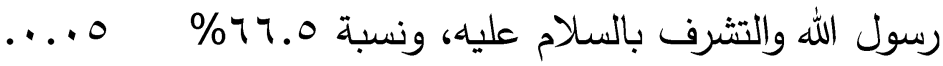
منهم يجذبهم الدروس الدينية التى يلقيها خطيب 1- مدى الحرص على الاستماع إلى دروس المسجد النبوى، ونسبة 0\% منهم يجذبهم بعض العلماء قبل الصلاة أو بعدها خلال زيارة أحاديث الرسول (ص) التى تحث على زيارة المسجد النبوي:

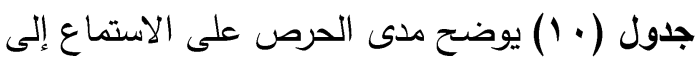
المسجد، ونسبة 0 \&V. منهم يجذبهم الاستفادة

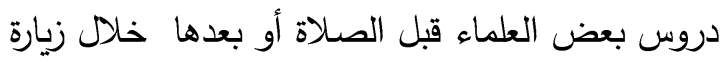
من التقنية الحديثة داخل المسجد (المكتبة / شرائط المسجد النبوي

\begin{tabular}{|c|c|c|c|c|}
\hline \multirow{2}{*}{ الد لالة } & \multirow{2}{*}{ كاץ } & \multicolumn{2}{|c|}{ الإجمالي } & \multirow{2}{*}{ 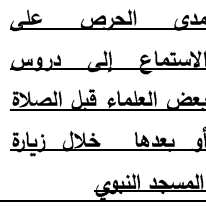 } \\
\hline & & $\%$ & ك & \\
\hline \multirow{3}{*}{$\cdots \cdot$} & \multirow{3}{*}{ Av.Ir. } & Nr & 174 & نعم \\
\hline & & IV & $r \varepsilon$ & y \\
\hline & & $1 \ldots$ & r.. & جملة \\
\hline
\end{tabular}

ويتضح وجود فروق في الاشياء التي تجذب المصريين لتكرار زيارتهم للمسجد النبوي والصلاة داخله، حيث كانت قيم كاب دالة عند مستوى دلالة اقل من 0....، فيما عدا الاستفادة من التقنية الحديثة داخل المسجد (المكتبة / شرائط 
ويتضح وجود فروق في مدى الحرص

مدى الحرص على الاستماع إلى دربس بعض العلماء قبل الصلادة أو بعدها خلا زيارة المسجد الثنبوي

على الاستماع إلى دروس بعض العلماء قبل

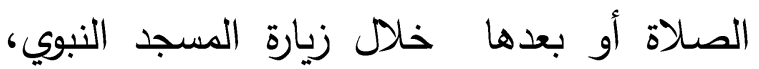

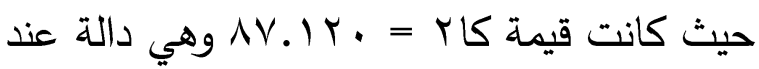
مستوى | (..... مما يعني ارتفاع نسبة لفؤاد العينة الحريصون على الاستماع إلى دروس بعض العلماء قبل الصلاة أو بعدها خلال زيارة

يتضح من الجدول السابق أن نسبة ب^\% من أفراد العينة حريصون على الاستماع إلى المسجد النبوي. ^-ترتيب اسباب اعجاب المصريون بأصوات علماء وخطباء المسجد النبوى:

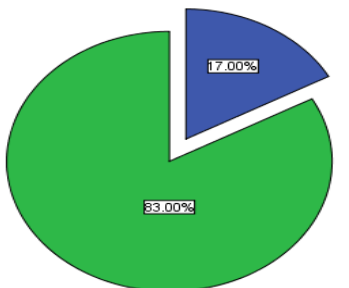

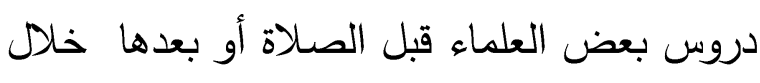
زيارة المسجد النبوي.

جدول (1 1) يوضح ترتيب اسباب اعجاب المصريون بأصوات علماء وخطباء المسجد النبون= . . ب

\begin{tabular}{|c|c|c|c|c|c|c|c|c|}
\hline \multirow{2}{*}{ 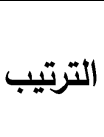 } & \multirow{2}{*}{ المرجت } & \multicolumn{6}{|c|}{ الترتيب } & \multirow{2}{*}{ 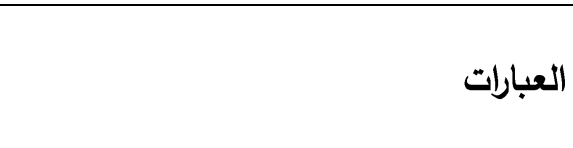 } \\
\hline & & 7 & 0 & $\varepsilon$ & $r$ & r & 1 & \\
\hline r & $\varepsilon . \wedge$ & r. & זו & 17 & $\mu \wedge$ & 09 & $\varepsilon \varepsilon$ & غزارة العلم الدينى \\
\hline 0 & r.91 & $T V$ & TI & 19 & TV & YA & 11 & 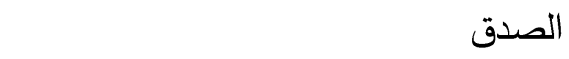 \\
\hline 1 & $\varepsilon .1 \leq$ & rt & $1 \varepsilon$ & IV & $\leqslant 9$ & $\wedge$ & $\Lambda$. & الاستقادة من علمهح للتثقه فى الدين \\
\hline 7 & r.07 & 71 & 11 & 77 & Tr & $1 \leqslant$ & r & التواضع \\
\hline r & r.VI & r & r & 10 & . & $V Y$ & rA & 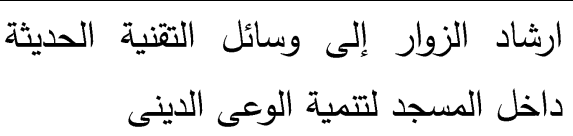 \\
\hline$\varepsilon$ & T.re & 1 & VI & $7 V$ & $1 \varepsilon$ & 19 & rᄉ & حسن الخلق ( الدين و الخلق ) \\
\hline
\end{tabular}

يتضح من الجدول السابق أن أفراد العينة - ارشاد الزوار إلى وسائل التقنية الحديثة داخل المسجد لتنمية الوعى الدينى في الترتيب ترتيب اسباب اعجاب المصريون بأصوات علماء

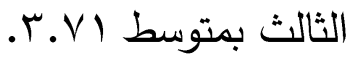
وخطباء المسجد النبوى: - الاستفادة من علمهم للتفقه فى الدين في - حسن الخلق ( الدين و الخلق ) في الترتيب

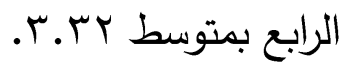
الترتيب الاول بمتوسط ؟ ا. ــ. - غزارة العلم الدينفي الترتيب الثاني بمتوسط - الصدق في الترتيب الخامس بمتوسط ا9. . . • 1 أهم ما يستفيده المسلمون من زيارتهم $. \varepsilon .+\wedge$ للمسجد النبوى: 
جدول (Y I ) يوضتح أهم ما يستفيده المسلمون من زيارتهم للمسجد النبوى

\begin{tabular}{|c|c|c|c|c|}
\hline \multirow{2}{*}{ د مستوى الالالة } & \multirow{2}{*}{ كاr } & \multicolumn{2}{|c|}{ الإجمالي } & \multirow{2}{*}{ أهم ما يستفيده المسلمون من زيارقم للمسجد النبوى } \\
\hline & & $\%$ & 5) & \\
\hline \multirow{6}{*}{$\cdots \cdots$} & \multirow{6}{*}{$\begin{array}{c}\text { r } \\
0.0\end{array}$} & 17.0 & 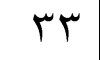 & خدمة العقيدة \\
\hline & & r) & $\varepsilon r$ & خدمة السنة النبوية \\
\hline & & $r \varepsilon .0$ & 79 & خدمة الفقه والفتوى \\
\hline & & $1 \varepsilon$ & rᄉ & زيارة مكتبة المسجد وتفقد أهم مقتنياتها \\
\hline & & $1 \varepsilon$ & rᄉ & اقتناء وسائل تقنية حديثة فى نشر العلم الشرعى \\
\hline & & $1 \cdots$ & r.. & جملة \\
\hline
\end{tabular}

11 - رأي أفراد العينة فى توسعة واعمار المسجد النبوى الأى جعل المسجد درة على

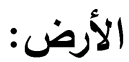

جدول (T I ) يوضح رأي افراد العينة فى توسعة واعمار

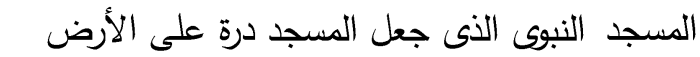

\begin{tabular}{|c|c|c|c|c|}
\hline \multirow{3}{*}{ د الدلالة } & \multirow{3}{*}{ كاr } & \multicolumn{2}{|c|}{ الإجمالي } & رأي افراد العينة في توسعة واعمار \\
\hline & & \multirow{2}{*}{$\%$} & \multirow{2}{*}{ ك } & المسجد النبوى الذى جعل \\
\hline & & & & المسجد درة على الأرض \\
\hline \multirow{12}{*}{$\ldots 0$} & \multirow{12}{*}{ ঙ.१^. } & \multirow{2}{*}{$r}$. & \multirow{2}{*}{ ?. } & توسعات لم تشهدها عمارة الممسجد \\
\hline & & & & من قبل \\
\hline & & & \multirow[b]{2}{*}{$\Lambda \varepsilon$} & قدمت راحة كبيرة لزوار المسجد \\
\hline & & $\varepsilon r$ & & النبوى للبقاء داخله اكبر وقت \\
\hline & & \multirow{7}{*}{ rA } & \multirow{7}{*}{04} & \\
\hline & & & & تتفق مع خصوصية التجربة \\
\hline & & & & السعودية وتوجهامًا الاسلامية \\
\hline & & & & الثابتة المستمدة من شرع الله الذى \\
\hline & & & & لا يتبدل ولا يتغير ولا يتأثر \\
\hline & & & & بسياسة أو غيرها ، والتى وضع \\
\hline & & & & لبنتها الأولى الرسول (ص) \\
\hline & & $1 \ldots$ & r... & جملة \\
\hline
\end{tabular}

أهم ما يستفيده المسلمون من زيارتهم للمسجد النبوى

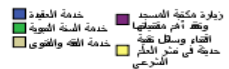

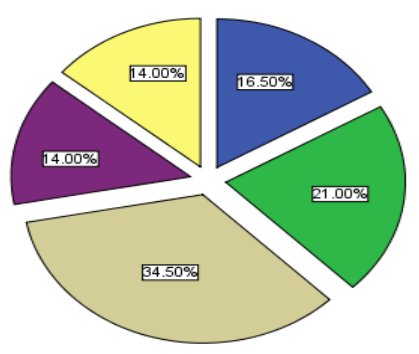

يتضح من الجدول السابق أن نسبة

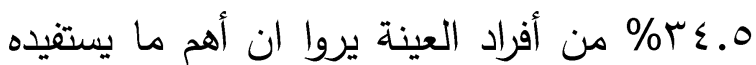
المسلمون من زيارتهم للمسجد النبوى هي خدمة الفقه والفتوى، ونسبة اYY\% منهج يروا أنه خدمة السنة النبوية، ونسبة 1 أ1\% منهخ يروا انه خدمة العقيدة.

ويتضح وجود فروق في أهم ما يستقيده

المسلمون من زيارتهم للمسجد النبوى، حيث كانت

قيمة كاب = . •Y.00 وهي دالة عند مستوى 
ونسبة \%rی\% منهم يروا انها تتفق مع خصوصية التجربة السعودية وتوجهاتها الاسلامية الثابتة المستمدة من شرع الله الذى لا يتبدل ولا يتغير ولا يتأثر بسياسة أو غيرها ، والتى وضع لبنتها

$$
\text { الأولى الرسول (ص). }
$$

ويتضح وجود فروق في رأي افراد العينة

فى توسعة واعمار المسجد النبوى فى العهد رأي افراد العينة في توسعة واعمار العرم النوى فى العها السعودى الثأى جعل المسجد درة على الأرض

السعودى الذى جعل المسجد درة على الأرض، ولى

يتضح من الجدول السابق أن نسبة بـ\%

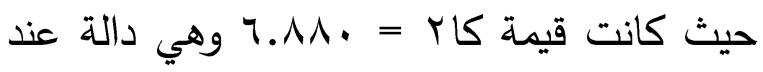

$$
\text { مستوى 0 . . . . }
$$

من أفراد العينة يروا فى توسعة واعمار الحرم النبوى فى العهد السعودى الذى جعل المسجد درة على الأرض قدمت راحة كبيرة لزوار المسجد النبوى للبقاء داخله اكبر وقت للاستفادة من التقنيات الحديثة داخله، ونسبة ، ب\% منهم يروا أنها توسعات لم تشهدها عمارة المسجد من قبل،

\begin{tabular}{|c|c|c|c|c|c|}
\hline \multirow{2}{*}{ مستوى الالالة } & \multirow{2}{*}{ كاr } & \multirow{2}{*}{ ترتيب } & \multicolumn{2}{|c|}{ الإجمالي ن= + . ب } & مقترحات لزيادة معرفة المسلمين بما يقدمه المسجد \\
\hline & & & $\%$ & ك5 & النبوى لحخدمة العلم الشرعى \\
\hline$\ldots \cdots$ & $T V . Y \wedge$. & 1 & 19 & 101 & إقامة معرض متتقل يجوب العالم عن المسجد \\
\hline VVV . • غير دالة & $\cdot . \wedge$ & r & $\leqslant q$ & 91 & توزيع نشرات وكتيات عن المسجد والاهتمام \\
\hline$\ldots+1$ & IT.Or. & r & זד & 1 1 & إقامة ندوات داخلية وخارجية عن فضل \\
\hline$\cdots+1$ & ON.Tt. & $\varepsilon$ & 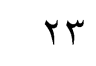 & $\leqslant 7$ & عمل رحلات في غير مواعيد الحج مخفضة \\
\hline
\end{tabular}
جدول (ء 1) يوضـح مقترحات لزيادة معرفة المسلمين بما يقدمه المسجد النبوى لخدمة العلم الثرعى

يتضح من الجدول السابق أن نسبة \% \% م داخلية وخارجية عن فضل المسجد النبوى، ونسبة من أفراد العينة يقترحوا لزيادة معرفة المسلمين 9٪\% منهح يقترحوا توزيع نشرات وكتيبات عن بما يقدمه المسجد النبوى لخدمة العلم الثرعى المسجد والاهتمام بالإعلام الجديد فى توعية إقامة معرض متتقل يجوب العالم عن المسجد المسلمين بأهمية المسجد النبوى. النبوى على غرار معرض الرياض بين الأمس لزيتضح وجود فروق في مقترحات واليوم، ونسبة ب7\% منهم يقترحوا إقامة ندوات معرفة المسلمين بما يقدمه المسجد النبوى لخدمة 
النبوى، حيث كانت قيمة كاץ = .01. • 1 وهي دالة عند مستوى | (..... مما يعني انخفاض نسبة افراد العينة الذين يروا وجود ازعاج او شعور بعدم الارتياح خلال زيارة المسجد النبوى. 1 - أهم العوامل التى اشعرت افراد العينة بالانزعاج أو عدم الإرتياح: جدول (7 1) يوضـح أهم العوامل التى اشعرت افراد العينة بالانزعاج أو عدم الإرتياح

\begin{tabular}{|c|c|c|c|c|}
\hline \multirow{2}{*}{ لد الالالة } & \multirow[b]{2}{*}{ Sו } & \multicolumn{2}{|c|}{ الإجمالي } & \multirow{2}{*}{ علهم الإرتياح التى اشعرت افراد العينة بلانزعاج أو } \\
\hline & & $\%$ & ك ك & \\
\hline \multirow{4}{*}{$\ldots o$} & \multirow{4}{*}{$\vee . \diamond \wedge \xi$} & 纟... & rv & 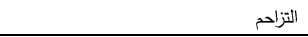 \\
\hline & & $r y . r$ & $r$ & عبم معرفة الأماكن \\
\hline & & $T \varepsilon . V$ & 19 & وجود لهجات كتيره \\
\hline & & 1.. & v v & جملة \\
\hline
\end{tabular}

أهم العوامل التى اشعرت افراد العينة بالانزعاج أو عدم الإرتياح

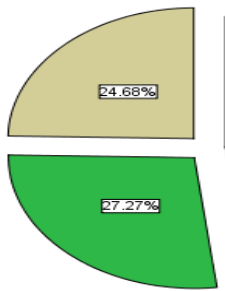

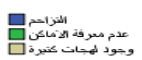

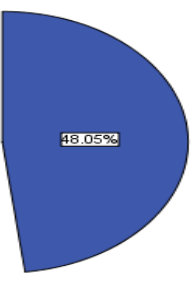

يتضح من الجدول السابق أن نسبة

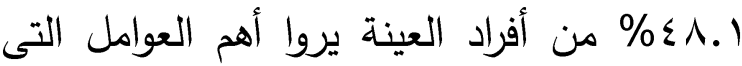
اشعرت افراد العينة بالانزعاج أو عدم الارتياح التزاحم، ونسبة r.r.r منهج يزعجهم عدم معرفة الاماكن، ونسبة V.Y\% منهح يزعجهج وجود لهجات كثيرة.

ويتضح وجود فروق في أهم العوامل التى اشعرت افراد العينة بالانزعاج أو عدم الارتياح، حيث كانت قيمة كاץ = £.0^ وهي دالة عند مستوى 0 . . •، مما يعني ارتفاع نسبة افراد العينة

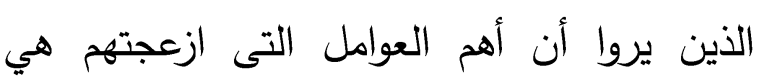

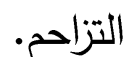

العلم الشرعى، حيث كانت قيم كاب دالة عند مستوى ا +... بينما لم يكن بينهم فروق في توزيع نشرات وكتيبات عن المسجد والاهتمام بالإعلام الجديد فى توعية المسلمين بأهمية المسجد النبوى حيث كانت قيم كاب غير دالة عند

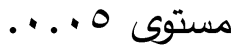
سا - مدى وجود ازعاج او شعور بعدم الارتياح خلال زبارة المسجد النبوى: جدول (0) يوضح مدى وجود ازعاج او شعور بعدم الارتياح خلال زيارة المسجد النبوى

\begin{tabular}{|c|c|c|c|c|}
\hline \multirow{2}{*}{ الدلالة } & \multirow{2}{*}{ كاr } & \multicolumn{2}{|c|}{ الإجمالي } & مدى وجو وجود ازعاج \\
\hline & & $\%$ & ك & المسجد النبوى خلال زيارة \\
\hline \multirow{3}{*}{$\cdots \cdots 1$} & \multirow{3}{*}{1.01} & rی.0 & $V V$ & نعم \\
\hline & & 71.0 & IrT & لا \\
\hline & & $1 \ldots$ & $r .$. & جملة \\
\hline
\end{tabular}

مدى وجود ازعاج او شعود بعدم الارتياح خلال زيارة المسجد النبوى

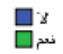

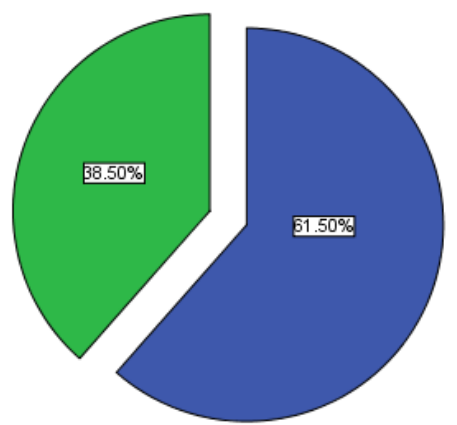

يتضـــح مـن الجـدول الســابق أن نسـبة

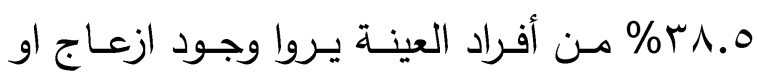
شعور بعدم الارتياح خلال زيارة المسجد النبوى. ويتضح وجود فروق في مدى وجود ازعاج او شعور بعدم الارتياح خلال زيارة المسجد 


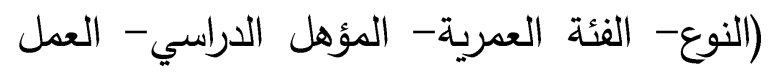
الإجابة عن فروض الدراسة : بالسعودية). تسعي الاراسة إلى اختبار الفروض التالية:

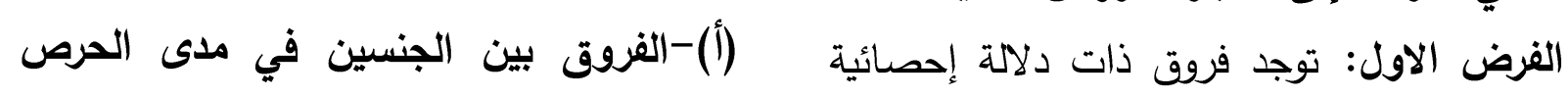

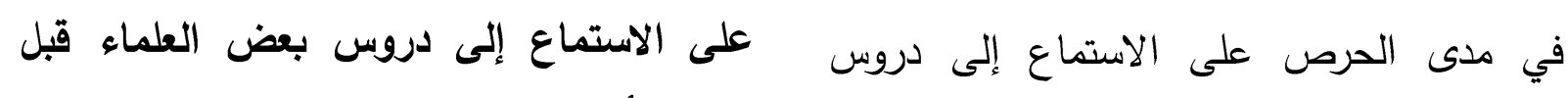

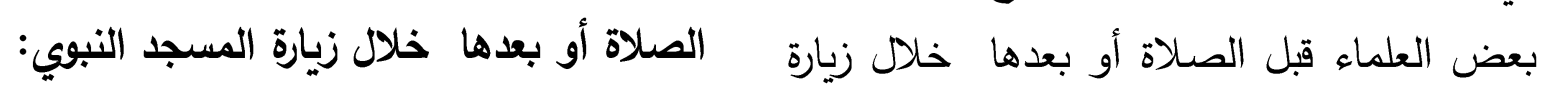

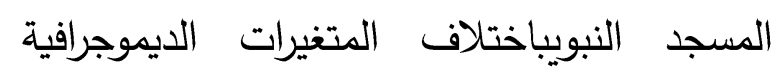

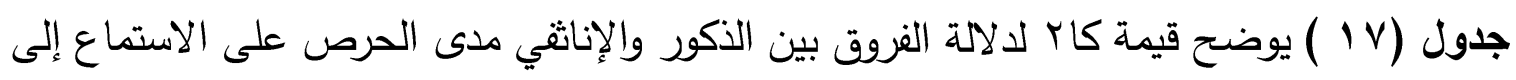

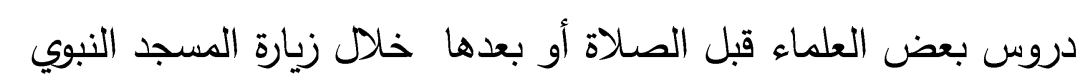

\begin{tabular}{|c|c|c|c|c|c|c|c|c|}
\hline \multirow{2}{*}{ د مستوى الالالة 1} & \multirow{2}{*}{ كاr } & \multicolumn{2}{|c|}{ إجمالي } & \multicolumn{2}{|c|}{ الإناث } & \multicolumn{2}{|c|}{ الأكور } & \\
\hline & & $\%$ & ك & $\%$ & ك & $\%$ & ك5 & \\
\hline \multirow{3}{*}{ •• •. غير دالة } & \multirow{3}{*}{$\because 1 \leqslant r$} & N & 174 & NT & NY & $\Lambda \varepsilon$ & $\Lambda \varepsilon$ & نعم \\
\hline & & IV & $\Gamma \varepsilon$ & 11 & 11 & 17 & 17 & V \\
\hline & & $1 \ldots$ & $r \ldots$ & $1 \ldots$ & $1 \ldots$ & $1 \ldots$ & $1 \ldots$ & الجملة \\
\hline
\end{tabular}

يتضح من الجدول السابق:عدم وجود (ب)- الفروق بين الفئات العمرية في درجة

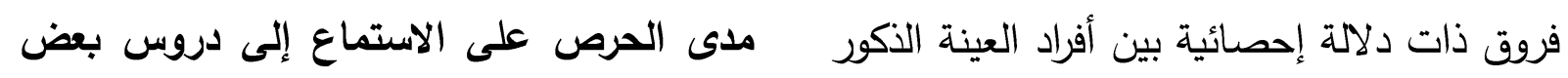

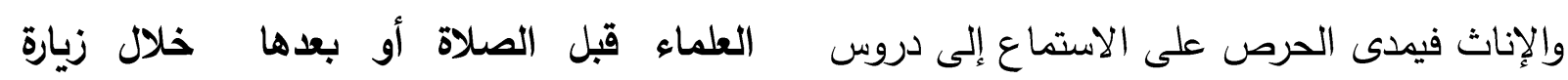

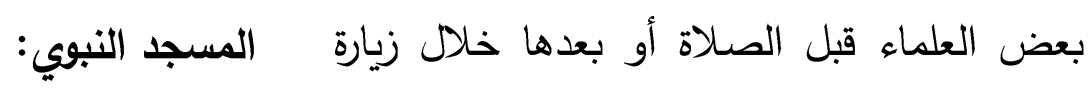

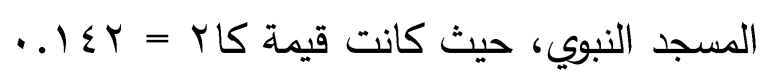
وهي غير دالة عند مستوى دلالة هـ ـ...

جدول (1 ا ) يوضح قيمة كاب لدلالة الفروق بين الفئات العمرية في مدى الحرص على الاستماع إلى

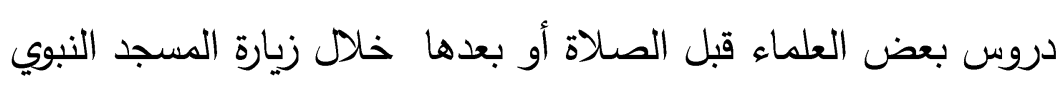




\begin{tabular}{|c|c|c|c|c|c|c|c|c|c|c|}
\hline \multirow{2}{*}{ د د حستوى الدلالة } & \multirow[t]{2}{*}{ كاr } & \multicolumn{2}{|c|}{ فن من مثر } & \multicolumn{2}{|c|}{ من بس - . . } & \multicolumn{2}{|c|}{ 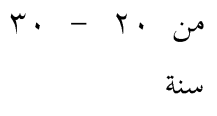 } & \multicolumn{2}{|c|}{ اقل من ·r سنة } & \\
\hline & & $\%$ & ك5 & $\%$ & 5) & $\%$ & 5) & $\%$ & 5) & \\
\hline \multirow{3}{*}{$\cdots \cdots 1$} & \multirow{3}{*}{$\begin{array}{r}0.0 \mathrm{~V} \\
\varepsilon\end{array}$} & or. & ro & $\begin{array}{c}\text { VA. } \\
r\end{array}$ & 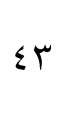 & $1 \ldots$ & 07 & $1 \cdots$ & $\varepsilon r$ & ن نعم \\
\hline & & $\leqslant 7$. & rr & ri. & 14 & - & - & - & - & Y \\
\hline & & $1 \ldots$ & $\varepsilon V$ & $1 \ldots$ & 00 & $1 \ldots$ & 07 & $1 \ldots$ & $\varepsilon r$ & الجمـلة \\
\hline
\end{tabular}

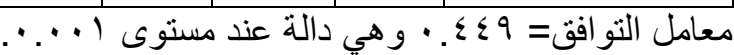

يتضح من الجدول السابق :وجود فروق ال(ج)- الفروق بين المؤهلات الدراسية في مدى الدئ

ذات دلالة إحصائية بين الفئات العمرية في مدى الحرص على الاستماع إلى دروس بعض العلماء الحرص على الاستماع إلى دروس بعض العلماء قبل الصلاة أو بعدها خلال زيارة المسجد قبل الصلاة أو بعدها خلال زيارة المسجد النبوي، النبوي:

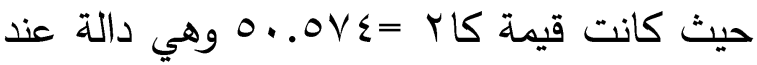
مستوى دلالة ا...... جدول (9 1) يوضح قيمة كاب لدلالة الفروق بين مدى الحرص على الاستماع إلى دروس بعض العلماء قبل الصلاة أو بعدها خلال زيارة المسجد النبوي

\begin{tabular}{|c|c|c|c|c|c|c|c|c|c|c|}
\hline \multirow{2}{*}{ الدلالة } & \multirow[b]{2}{*}{ كاr } & \multicolumn{2}{|c|}{ دراسات عليا } & \multicolumn{2}{|c|}{ تعليم جامعي } & \multicolumn{2}{|c|}{ تعليم متوسط } & \multicolumn{2}{|c|}{ اقل من متوسط } & \multirow[b]{2}{*}{ السن } \\
\hline & & $\%$ & 5 & $\%$ & ك & $\%$ & كs & $\%$ & ك & \\
\hline \multirow{3}{*}{$\cdots \cdots$} & \multirow{3}{*}{$19 . V Y}$. & 0 . & $\wedge$ & $\vee \wedge .1$ & 0. & 90 & OV & 10 & 01 & نعم \\
\hline & & 0 . & $\wedge$ & Y1.9 & $1 \varepsilon$ & 0 & r & 10 & 9 & $\gamma$ \\
\hline & & $1 \ldots$ & 17 & $1 \ldots$ & $7 \varepsilon$ & $1 \ldots$ & 7. & $1 \ldots$ & 7. & الجمـلة \\
\hline
\end{tabular}

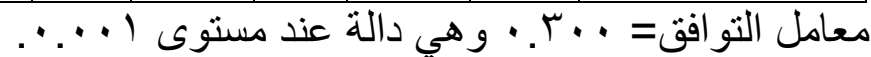

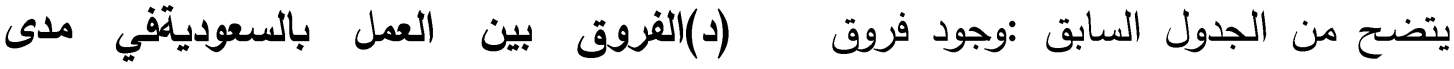
ذات دلالة إحصائية بين المؤهلات الدراسية في الحرص على الاستماع إلى دروس بعض العلماء مدى الحرص على الاستماع إلى دروس بعض قبل الصلاة أو بعدها خلال زيارة المسجد العلماء قبل الصلاة أو بعدها خلال زيارة المسجد النبوي: النبوي، حيث كانت قيمة كاr =. .9.9 اوهي دالة عند مستوى دلالة ا....... 
جدول (·r) يوضح قيمة كاب لدلالة الفروق بين العمل بالسعودية في مدى الحرص على الاستماع إلى

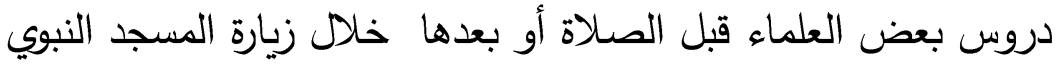

\begin{tabular}{|c|c|c|c|c|c|c|c|c|c|c|}
\hline \multirow{2}{*}{ د د حستوى الدلالة } & \multirow{2}{*}{ SLI } & \multicolumn{2}{|c|}{ عمل موسمي } & \multicolumn{2}{|c|}{ اعمال الحلكومة } & \multicolumn{2}{|c|}{ اعمال قطاع خاص } & \multicolumn{2}{|c|}{ لا يعمل } & \\
\hline & & $\%$ & 5) & $\%$ & 5 & $\%$ & 5) & $\%$ & 5) & \\
\hline \multirow{3}{*}{$\cdots 1$} & \multirow{3}{*}{ I T.YAT } & $\Lambda T$ & $\varepsilon r$ & $7 r .9$ & rr & $\wedge \vee . \wedge$ & $\vee q$ & $\wedge \wedge$ & rr & نعم \\
\hline & & $1 \varepsilon$ & V & rV.I & IT & IY.Y & 11 & ir & $r$ & V \\
\hline & & $1 \ldots$ & 0. & $1 \ldots$ & ro & $1 \ldots$ & 9. & $1 \ldots$ & ro & الجمـلة \\
\hline
\end{tabular}

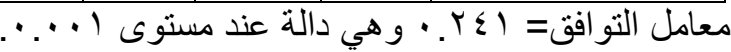

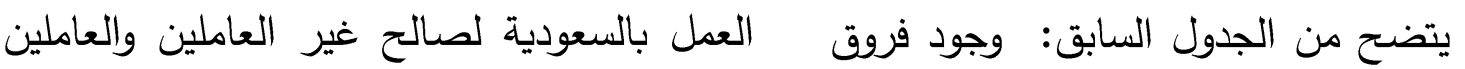

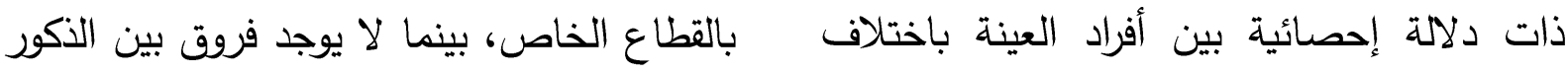

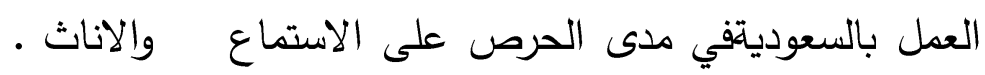

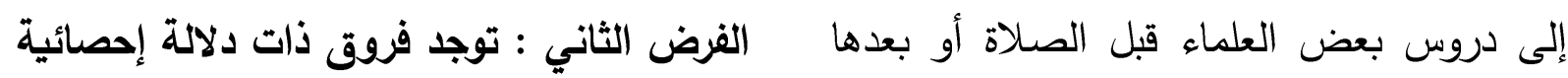

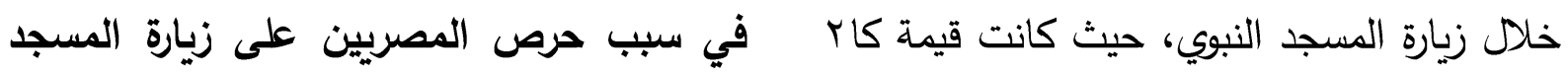

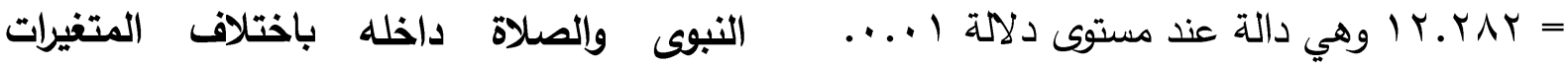
مما سبق يتضح تحقق الفرض الاول الديموجرافية ( النوع- الفئة العمرية- المؤهل-

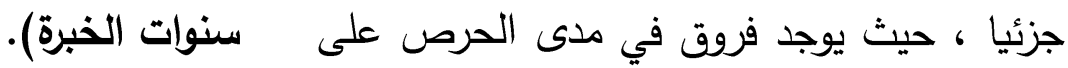

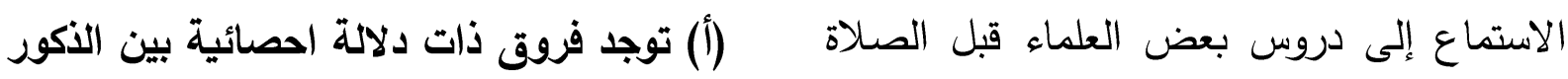
أو بعدها خلال زيارة المسجد النبوي باختلاف والإناثناث فيسبب حرص المصريين على زيارة الفئات العمرية لصالح الفئات الاصغر سنا وبين المسجد النبوى والصلاة داخله: المؤهلات الدراسية لصالح الاقل تعليما وبين فئات

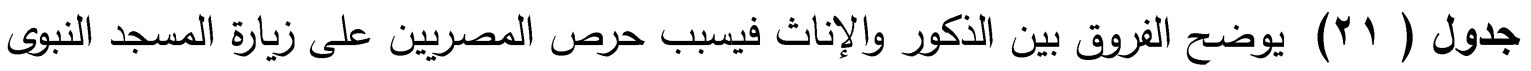
والصلاة داخله

\begin{tabular}{|c|c|c|c|c|c|c|}
\hline \multirow{2}{*}{ مستوى المعنوية } & \multirow{2}{*}{ ت } & \multicolumn{2}{|c|}{ إناث(ن 1) } & \multicolumn{2}{|c|}{ ذكور (ن= - . 1) } & \multirow[t]{2}{*}{ الجنس } \\
\hline & & $\varepsilon$ & م & $\varepsilon$ & م & \\
\hline$\ldots \ldots 1$ & 11.VTr &. .909 & r.V & $1 . .1 \mathrm{~V}$ & $\varepsilon . r$ & سبب حرص المصريين على زيارة المسجد النبوى \\
\hline
\end{tabular}

يتضح من الجدول السابق وجود فروق ب(ب)-توجد فروق ذات دلالة احصائية بين

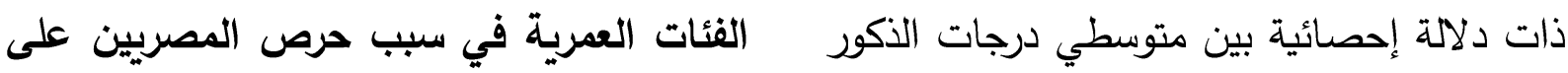
والإناث في سبب حرص المصريين على زيارة زيارة المسجد النبوى والصلاة داخله: المسجد النبوى والصلاة داخله لصالح الذكور، حيث كانت قيمة (ت) دالة عند مستوى ل......... 

جدول ( r r يوضح الفروق في سبب حرص المصريين على زيارة المسجد النبوى والصلاة داخله باختلاف الفئات العمرية

\begin{tabular}{|c|c|c|c|c|c|c|}
\hline معنوية & فـ & متوسط & $\tau \cdot s$ & مجموع الدرجات & البيان & الفروق تبعا إلى \\
\hline \multirow{3}{*}{$\cdots+1$} & \multirow{3}{*}{$\leq 7.704$} & $\varepsilon 0.0 \mathrm{TV}$ & r & $1+4.71$. & بين مجموعات & سبب حرص المصريين على \\
\hline & & $.9 \mathrm{V7}$ & 197 & 191.41. & داخل & المسجد \\
\hline & & & 199 & TrV.qY. & 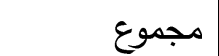 & والصلاة داخله \\
\hline
\end{tabular}

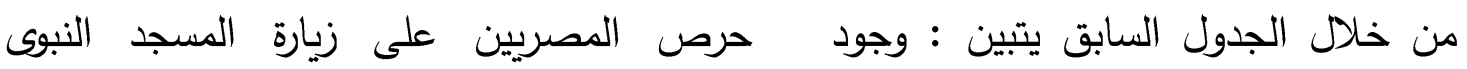
فروق ذات دلالة إحصائية بين متوسطات درجات والصلاة داخله، حيث كانت قيمة (ف)دالة عند

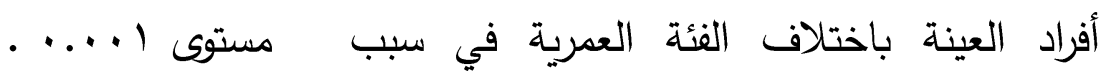
جدول (r r)يوضح الدقارنات الثنائية سبب حرص المصريين على زيارة المسجد النبوى والصلاة داخله بين الفئات العمرية

\begin{tabular}{|c|c|c|c|c|c|c|c|c|}
\hline سنة فاكثر & من • مبة - منة & 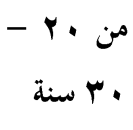 & سنة من • اقل & انخراف & متوسط & ن ن & & الفئة العمرية \\
\hline *1. & $\begin{array}{r}- \\
* 1 . \wedge 11 \%\end{array}$ & $\begin{array}{r}- \\
\text { *Y. T }\{\varepsilon 1\end{array}$ & & $1 . .01$ & 1.9 & $\varepsilon Y$ & اقل من · Y سنة & \multirow{5}{*}{ 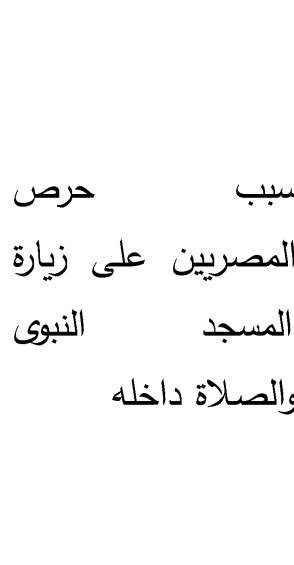 } \\
\hline דצדיזיט & *.. . ETY人 & & & $1 . T \varepsilon Y$ & $\varepsilon . T$ & 07 & من • بنة - مب & \\
\hline \multirow[t]{3}{*}{$\begin{array}{r}- \\
\ldots 74 r\end{array}$} & & & &. .774 & r.A & 00 & من .ب - م. & \\
\hline & & & & .1194 & r. & $\varepsilon V$ & 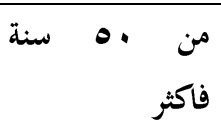 & \\
\hline & & & & $1 . T \wedge \varepsilon$ & r.o & $r .$. & جملة & \\
\hline
\end{tabular}

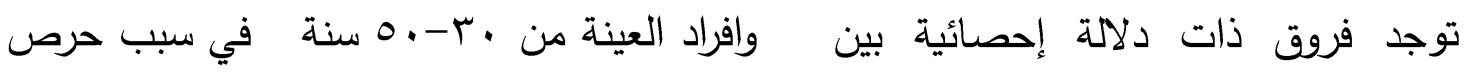

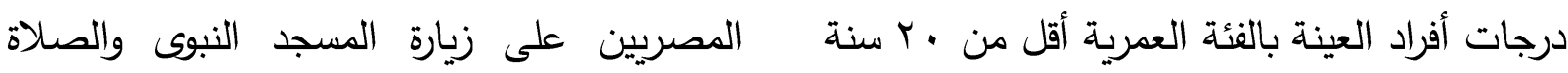

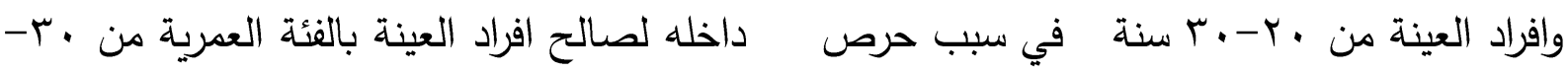

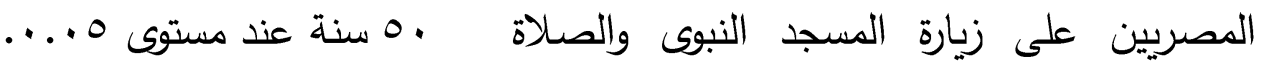
وجود فروق ذات دلالة إحصائية بين

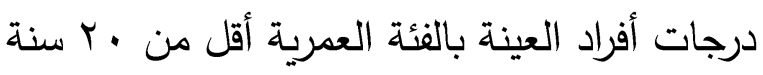

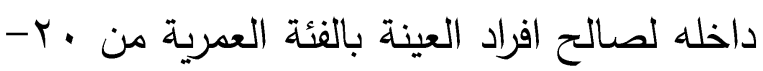

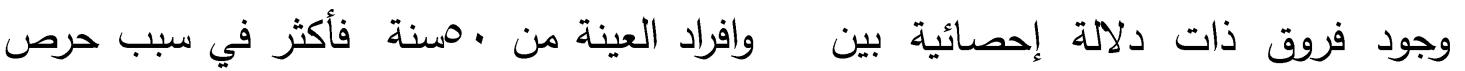

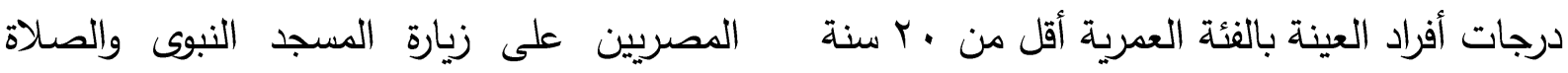




\begin{tabular}{|c|c|c|c|c|c|c|}
\hline مستوى معنية & ف & متوسط & $\begin{array}{c}1 \\
\tau\end{array}$ & مجموع & البيان & تبعا إلى \\
\hline \multirow{3}{*}{ غير دالة. } & & $1.9 \leqslant \varepsilon$ & $r$ & $0 . \lambda r$ & بين & عرصب \\
\hline & & 1. & 197 & Tr..A9 & داخل & المسجد \\
\hline & & & 199 & TrY.qY. & مجموع & دالضلهاة \\
\hline
\end{tabular}

من خلال الجدول السابق يتبين : عدم

وجود فروق ذات دلالة إحصائية بين متوسطات درجات أفراد العينة باختلاف المؤهل الدراسي في سبب حرص المصرين على زيارة المسجد النبوى والصلاة داخله، حيث كانت قيمة (ف) غير دالة

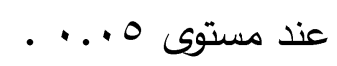
(د)-توجد فروق ذات دلالة احصائية بين فئات العمل بالسعودية في سبب حرص المصريين على زيارة المسجد النبوى والصلاة داخله:

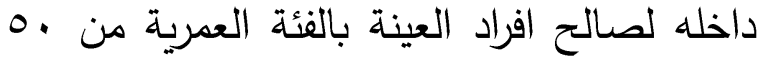
سنة فأكثر عند مستوى 0 ... . . وجود فروق ذات دلالة إحصائية بين درجات أفراد العينة بالفئة العمرية من •r-برد سنة وافراد العينة من .r-.0 سنة في سبب حرص المصرين على زيارة المسجد النبوى والصلاة داخله لصالح افراد العينة بالفئة العمرية من •r-. "r سنة عند مستوى 0 .... (ج)-توجـد فـروق ذات دلالـة احصـائية بـين المؤهلات الدراسية في سبب حرص المصرين على زيارة المسجد النبوى والصلاة داخله: جدول (צr) يوضح المقارنات الثائية سبب حرص المصريين على زيارة المسجد النبوى والصهلاة داخله بين المؤهلات الدراسية

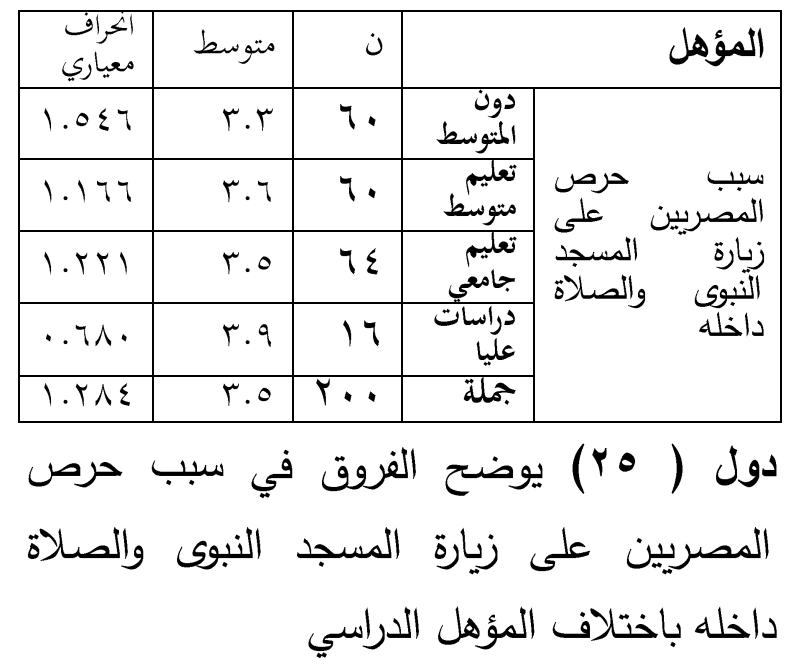

جدول ( צr) يوضح الفروق في سبب حرص المصرين على زيارة المسجد النبوى والصـلاة داخله باختلاف فئات العمل بالسعودية

\begin{tabular}{|c|c|c|c|c|c|c|}
\hline مستوى معنوية & ف & متوبط & I. & مجموع الدرجات & البيان & الفروق تبعا إلى \\
\hline \multirow{3}{*}{$\cdots 1$} & \multirow{3}{*}{$\varepsilon .00 \mathrm{~V}$} & V.IYV & $r$ & YI.rAY & بين مجموعات & \multirow{3}{*}{ 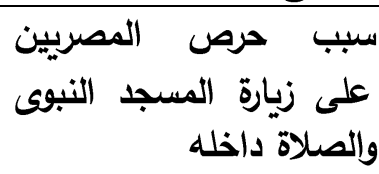 } \\
\hline & & $1.07 \varepsilon$ & 197 & $r .7 .0 r \wedge$ & داخل & \\
\hline & & & 199 & TYV.9Y. & مجموع & \\
\hline
\end{tabular}


من خلال الجدول السابق يتبين : وجود سبب حرص المصريين على زيارة المسجد النبوى فروق ذات دلالة إحصائية بين متوسطات درجات والصلاة داخله، حيث كانت قيمة (ف)دالة عند

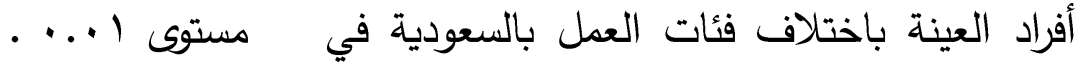

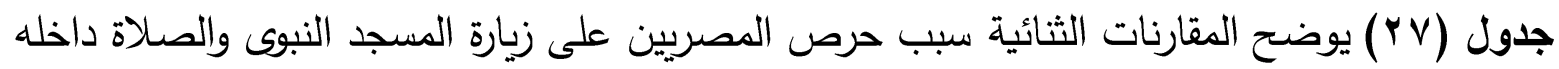
بين فئات العمل بالسعودية

\begin{tabular}{|c|c|c|c|c|c|c|c|c|}
\hline عمل موسمي & عمل حكومي & قطاع خاص & لا & انمراف & | لمتوسط & ن & \multicolumn{2}{|c|}{ فئات العمل بالسعودية } \\
\hline$*$ *. . & ${ }^{*} 1.170 \mathrm{~V}-$ & D. O.TYT- & & $1 . \varepsilon 1 r$ & $r . q$ & ro & لا تعمل & \multirow{5}{*}{ المبل } \\
\hline . $\vee \gamma \vee \wedge-$ & *.. . $74 r 0-$ & & & 1.r人a & r. $\varepsilon$ & 9. & خاصل ق قطاع & \\
\hline \multirow[t]{3}{*}{ तथर०० } & & & & $1 . \varepsilon .1$ & \&.1 & ro & عمل حكومي & \\
\hline & & & & .749 & $r .7$ & 0 . & عمل موسمي & \\
\hline & & & & $1 . Y \Lambda \varepsilon$ & r.o & r.. & جملة & \\
\hline
\end{tabular}

وجود فروق ذات دلالة إحصائية بين والصلاة داخله لصالح افراد العينة العاملين بالعمل

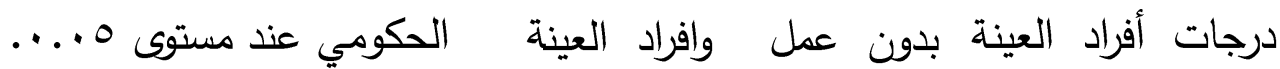

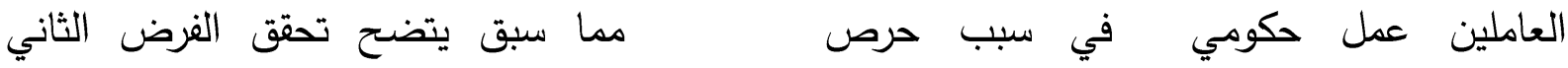
المصريين على زيارة المسجد النبوى والصلاة جزئيا ، حيث يوجد فروق في سبب حرص داخله لصالح افراد العينة العاملين بالعمل المبل المصريين على زيارة المسجد النبوى والصلاة داخله باختلاف النوع لصالح الذكور وباختلاف الحكومي عند مستوى 0...

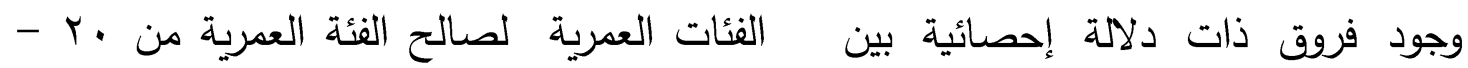
درجات أفراد العينة بدون عمل وافراد العينة ·r سنة وبين فئات العمل بالسعودية لصالح

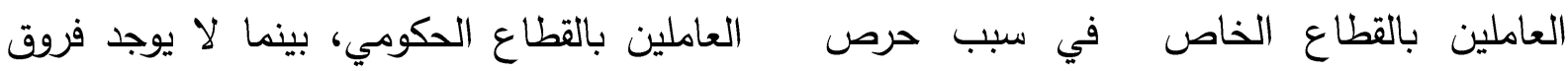
المصرين على زيارة المسجد النبوى والصلاة بين المؤهلات الدراسية .

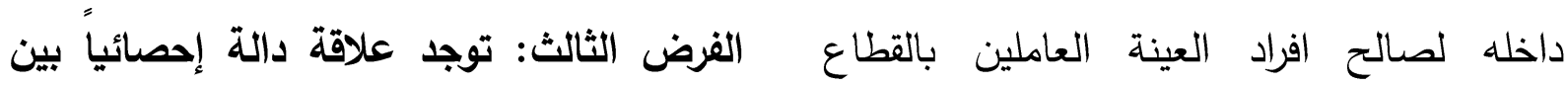
زيارة المسجد النبوى من قبل النبوي و الحرص المقاء الخاص عند مستوى 0... وجود فروق ذات دلالة إحصائية بين على البقاء فى المسجد بعد الصلاة

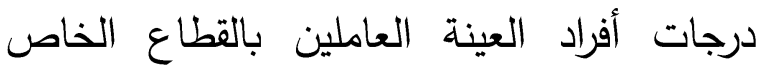

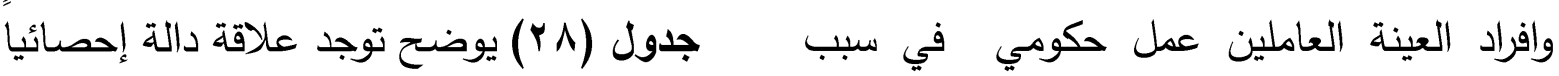

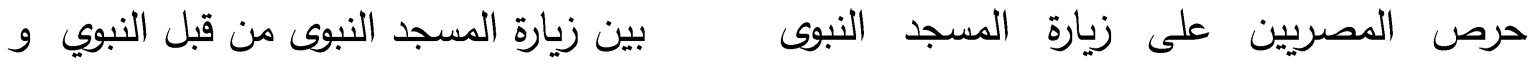
الحرص على البقاء فى المسجد بعد الصلاة 


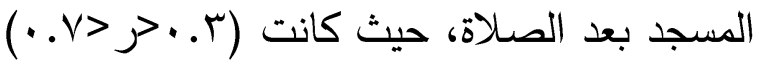

وهي دالة عند مستوى ا +..... ، اي كلما زادت

مرات زيارة المسجد النبوى من قبل النبوي قل قل

الحرص على البقاء فى المسجد بعد الصدلاة.

الفرض الرابع: توجد علاقة دالة إحصائياً بين

زيارة المسجد النبوى من قبل النبوي و الحرص على الاستماع إلى دروس بعض العلماء قبل هن

\begin{tabular}{|c|c|c|c|c|c|}
\hline \multicolumn{4}{|c|}{ زيارة المسجد النبوى من قبل النبوي } & & \multirow[b]{2}{*}{ المتغير } \\
\hline الد لالة & القوة & الاتجاه & معامل & & \\
\hline$\ldots 1$ & متوسط & عكسي & $* * . \leqslant \circ V$ & على & لالكرصاء \\
\hline
\end{tabular}

يتضح من الجدول السابق : الصلاة أو بعدها خلال زيارة المسجد النبوي.
-وجود علاقة عكسية متوسطة بين زيارة المسجد النبوى من قبل النبوي و الحرص على البقاء فى جدول (q ج) يوضـح توجد علاقة دالة إحصائيا بين زيارة المسجد النبوى من قبل النبوي و الحرص على الاستماع إلى دروس بعض العلماء قبل الصـلاة أو بعدها خلال زيارة المسجد النبوي

\begin{tabular}{|c|c|c|c|c|}
\hline \multicolumn{4}{|c|}{ زيارة المسجد النبوى من قبل النبوي } & \multirow[b]{2}{*}{ المتغير } \\
\hline 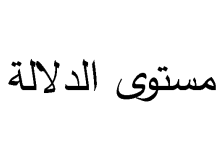 & القوة & الاتجاه & الارتباط & \\
\hline$\cdots 1$ & ض ت بعيف & 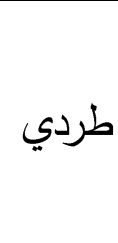 & $* * . r q$ & 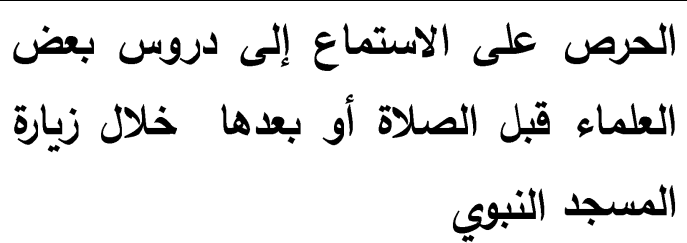 \\
\hline
\end{tabular}

الحرص على الاستماع إلى دروس بعض العلماء يتضح من الجدول السابق :

قبل الصلاة أو بعدها خلال زيارة المسجد النبوي. -وجود علاقة طردية ضعيفة بين زيارة المسجد النبوى من قبل النبوي و الحرص على الاستماع -توجد فروق ذات دلالة احصائية بين زيارة إلى دروس بعض العلماء قبل الصلاة أو بعدها المسجد النبوى من قبل وبين الثعور بالانزعاج خلال زيارة المسجد النبوي، حيث كانت (ردس. ) وعدم الارتياح خلال زيارة المسجد النبوى: وهي دالة عند مستوى ا +..... ، اي كلما زادت مرات زيارة المسجد النبوى من قبل النبوي زي زاد

جدول ( • ) يوضح قيمة كاب لدلالة الفروق بين زيارة المسجد النبوى من قبل وبين الثعور بالانزعاج وعدم الارتياح خلال زيارة المسجد النبوى 


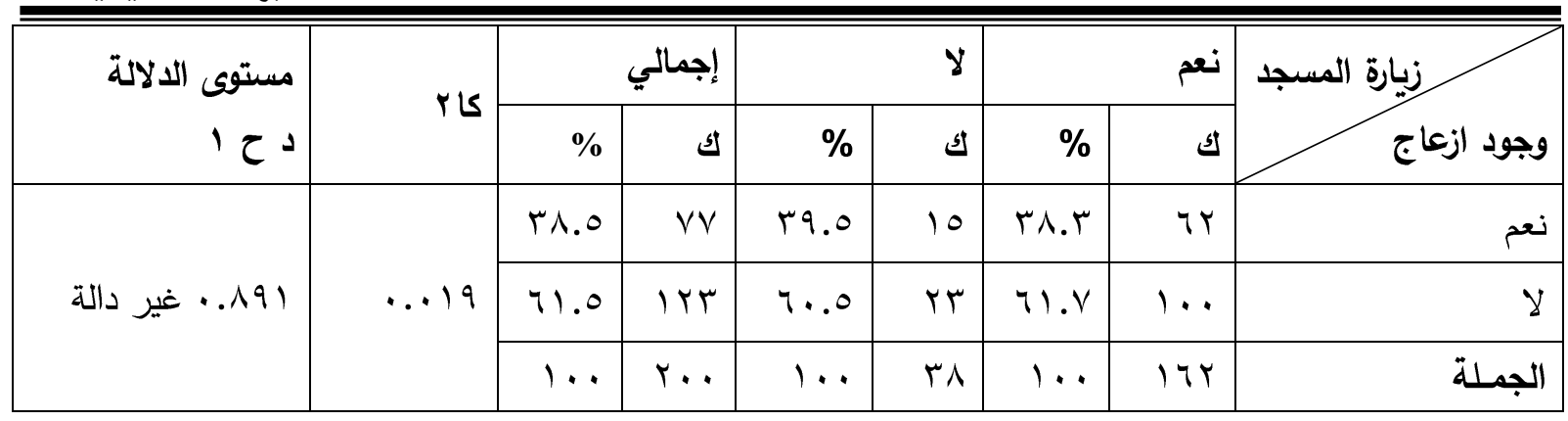

مسائل مضببة لديهم يلى ذلك الاستفادة من غزارة العلم الدينى لدى علماء المسجد النبوى. ع- أن الامكانات التقنية المتاحة داخل الحرم النبوى ( مصاحف / شرائط / تسجيلات ... إلخ ) لا تتم الاستفادة منها بشكل كامل داخل

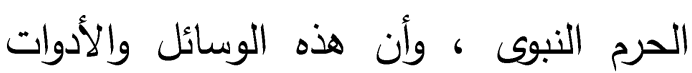
يجب الإعلام عنها داخل الحرم النبوى لتكون الاستفادة على مستوى أكبر • 0- تختلف الاستفادة من التقنيات داخل الحرم باختلاف درجة التحصيل العلمى للزائر ، وانها ترتفع كلما ارتقى المستوى العلمى لزائر الحرم ... وهذه النتيجة منطقية حيث أن غير المتعلمين أو أصحاب المؤهلات الأقل يكونوا مضغوطين في أعمالهم دائما بعكس الحاصلين على مؤهلات عليا باعتبارهم الأعلى غالبا فى الوظيفة التى توفر لهح الساعات التى يمكن فيها تكرار زيارة الحرم •

\section{أهم مراجع وهوامش الدراسة}

1 - رحلة الحج بالحنجرة المصرية ، محمد حمد مستجاب، صحيفة "المصري اليوم"،

$$
\text { (11/1/r. }
$$

يتضح من الجدول السابق:عدم وجود فروق ذات دلالة إحصائية بين أفراد العينة ممن سبقوا زيارة المسجد النبوي ومن لم يسبق لهم زيارته في والإناث فيالشعور بالانزعاج وعدم الارتياح خلال زيارة المسجد النبوى، حيث كانت قيمة كاץ = 9 1 ... وهي غير دالة عند مستوى دلالة 0....

\section{النتائج النهائية للدراسة :} اسفرت النتائج النهائية للدراسة عن التالى : 1- حرص المصريين العامليين فى أماكن عمل بالمدينة المنورة ، أو قريبين منها ، على زيارة المسجد النبوى خاصة وأن بعض زوجات أو أمهات بعض العاملين فى المملكة حتى و إن لم يزوروا الحرم النبوى يرون أن هذه الزيارة ضمن شعائر الحج ، بل إن البعض من غير المتعلمين يرون زيارة قبر الرسول (ص) حجة فى حد ذاتة . r- أن أغلب المصرين يرى أن زيارة المسجد النبوى (ص) ضمن شعائر الحج ولديهم الرغبة فى تكرارها مرات ومرات .

r- أن النسبة الغالبة على زوار الحرم النبوى (\%^r\%) يحرصن على دروس بعض العلماء قبل الصلاة فى المسجد النبوى أو بعدها ، بعل وهم يهدفون بذلك إلى التققة فى الدين فى 
لخضر، كلية الآداب والعلوم الإنسانية:

$$
\cdot()^{2} \cdot \cdot d
$$

- دور البرامج الحوارية في في تشكيل

اتجاهات الجمهور نحو الدور السياسي

للتيارات الإسلامية في مصر، سهام محمد عبد الخالق، المجلة المصرية لبحوث

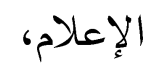

1- دور البرامج الحواريـة في تشكيل اتجاهات الجمهور نحو الدور السياسي للتيارات الإسلامية في مصر، سهام تحمد عبد الخالق، المجلة المصرية لبحوث

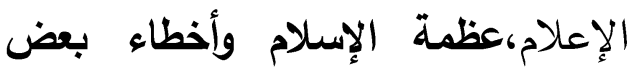
المنتسبين إليه: طريق التصحيح، مجموعة دراسات قدمها عدد من الباحثين للمؤتمر العام الرابع والعشرين، الذى عقده المجلس الأعلى للثؤون الإسلامية في 9

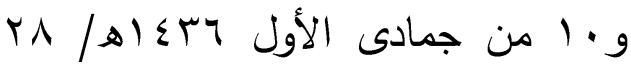
فبراير والأول من مارس 10 م .بم.

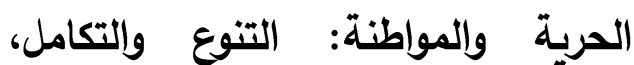
مجموعة دراسات قدمت إلى مؤتمر الأزهر ومجلس حكماء المسلمين الذى انعقد في القاهرة في الأول والثاني من

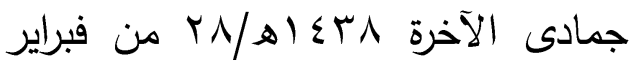

$$
\text { والأول من مارس VI الم آم. }
$$

• مسعود بن تركي الطويرقي، الطبعة

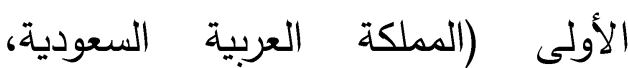
الرياض، مطابع الفرزدق التجارية:

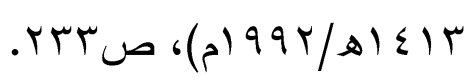

r- السيرة النبوية العطرة، السيد عبد الفتاح إبراهيم بلاط، (القاهرة، الجريسي

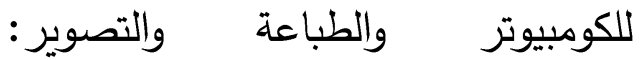
$\cdot(a r \cdot) \varepsilon$ و: الحجاز والحرمان الثريفان في القرن الثالث عشر، جعفر شهيدي (الرياض، جامعة الملك سعود: د.ت). r- السيرة النبوية في ض ضوء المصادر الأصلية: دراسة تحليلية ، مهدي رنق الله أحمد، الطبعة الأولى (الرياض، مركز الملك فيصل للبحوث والدراسات

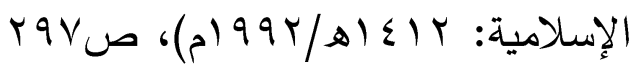
g ع- كلمة خادم الحرمين الثريفين الملك سلمان بن عبد العزيز؛ في الاحتفال باليوم الوطني للمملكة نقلا عن: - وكالة الأنباء السعودية (داس).

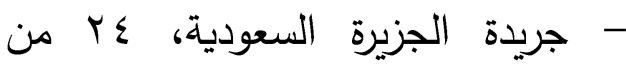
رمضنان qrعاهـ ع r من أيلول

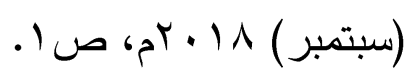

0- صوت الإمام: الخطاب الايني من السياق إلى التقلي، أحمد زايد، طا لإسي

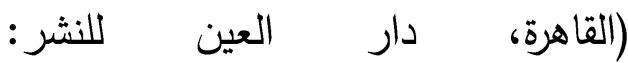

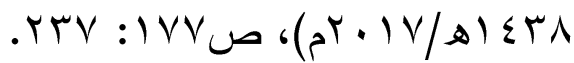
7- تجليات الحجاج في الخطاب النوبي: دراسة في وسيائل الإقناع الأربعون النووية أنموذجا، هشام فروم، ماجستير غير منشورة (الجزائر، جامعة الحاج 
- أ.د.رفعت البدري، عميد كلية الإعلام

وفنون الاتصال بالشارقة/ الإمارات

العربية المتحدة، وكيل كلية الإعلام وفنون

$$
\text { الاتصال بجامعة } 7 \text { أكتوبر . }
$$

- فوزي مخيم ؛ نائب رئيس تحرير صحيفة

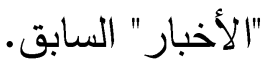

- أ.حمد القصبي؛ مدير تحرير صحيفة "الأخبار المسائي". - أ.د.تحم وهدان؛ رئيس قسم الإعلام في كلية الدراسات الإسلامية للبنات/ جامعة

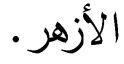

- أ.د.محمود عبد العاطي مسلم؛ أستاذ الراديو والتليفزيون في كلية الإعلام/ جامعة الأزهر - المردو ع ا منظومة القيم: سياسات استعادة التوازن في مراحل ما بعد الثورات، محمد محمود السيد، مجلة "مفاهيم المستقبل"، العدد فبراير 0 • "rام (القاهرة، مركز "V" المستقبل للأبحاث والدراسات المتقدمة:

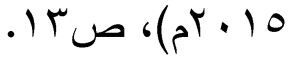

10 الطويرقي، مرجع سابق، صس ا |.
11- راجع في هذه النقطة البحثية:

- البحث العلمي: مناهجه وتقنياته،

محمد زيان عمر، الطبعة الأولى

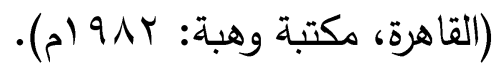

- الصدق والثبات في استمارتي الاستقصاء وتحليل المضمون، سلوى إمام، المجلة العلمية لكلية الإعلام، العدد الأول (جامعة القاهرة، كلية

$$
\text { الإعلام: يوليو 9199 (م). }
$$

- تحليل المحتوى في بحوث الإعلام، حمح عبد الحميد (جدة، دار الشروق:

$$
\text { .) (a) }
$$

- - بحوث الإعلام: الأسس والمبادئ، سمير حسين (القاهرة، عالم الكتب:

$$
\text { . (م) } 9 \wedge \mu
$$

\section{2-Mass Communication Theories} and research, Grid Publishing, Columbus O: 1981.

13-Joseph Dominick, The Dynamics of mass communication Reading (New York, Addison - Wesley: 1983. (**) محكمو الاستمارة؛ ممن سبق لهم زيارة الحرم النبوي؛ الأستاذة والخبراء:

- د.إسماعيل إبراهيم، مدير تحرير صحيفة "الأهرام" سابقا/ عضو هيئة التدريس في

كلية الإعلام وفنون الاتصال بجامعة 7 أكتوبر • 


\section{استماره استقصاء

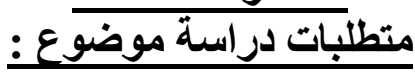

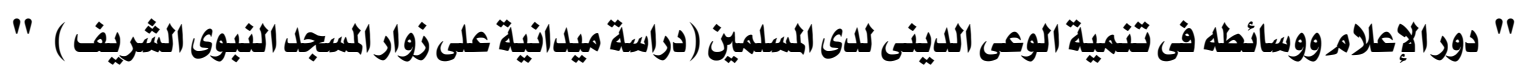

$$
\begin{aligned}
& \text { مقدم من }
\end{aligned}
$$

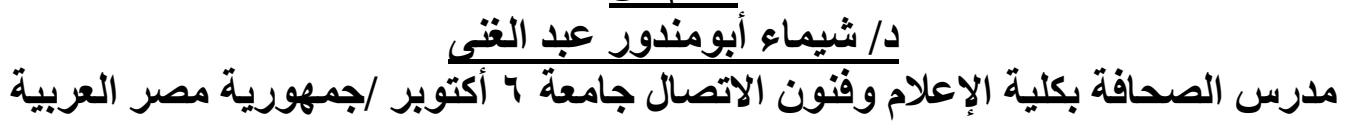

$$
\begin{aligned}
& \text { P. r./ D I } 1 \leqslant \leqslant r
\end{aligned}
$$

الأخ المصرى المقيم فى المدينة المنورة :

$$
\text { السلام عليكم ورحمة الله وبركاتة ............ بعد / }
$$

فى إطار زيارتكم للمسجد النبوى الثريف للصلاة أو للزيارة أو لتفقد بعض وسائل التقنية الحديثة

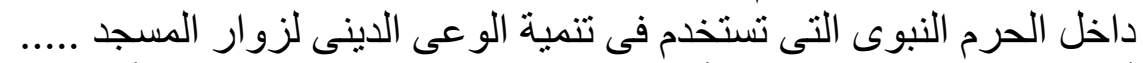

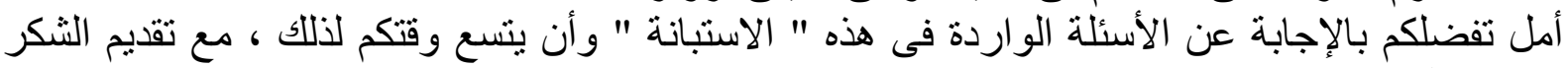
( الباحثة )

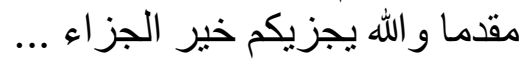




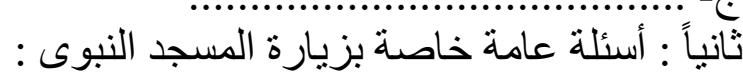

7 - هل سبق للك زيارة المسجد النبوى ؟

( فى حالة الاجابة ب (نعم) أجب عن سؤال (ع (ع ) وفى حالة الاجابة ب (لا) انتقل إلى سؤال رقم (ج) ) .

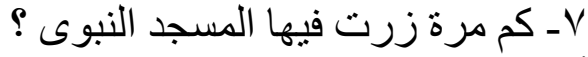

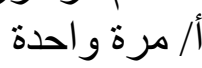

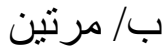
ج/ تخلاث مر اتثن د/ أكثر

1ـ هل كانت هذه الزيار ات مرتبطة بقدومك إلى المملكة العربية السعودية (المدينة المنورة) للعمل ؟ 
9 - ما رأيك فى حرص المصريين على زيارة المسجد النبوى و الصلاة داخله ؟

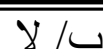

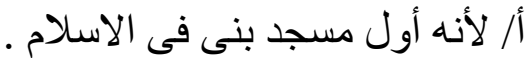

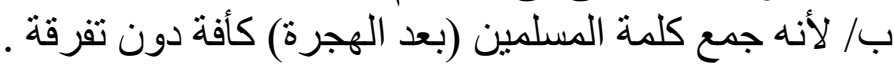

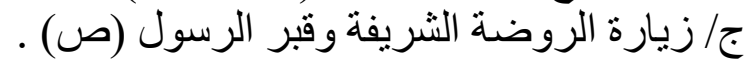

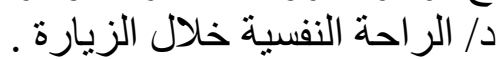
/ أداء الصلو ات خلال الزيارة خلارل خاصة صلارة صلاة الفجر .

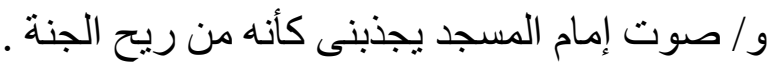

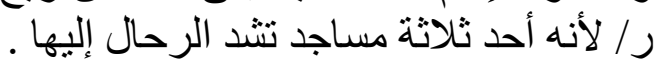

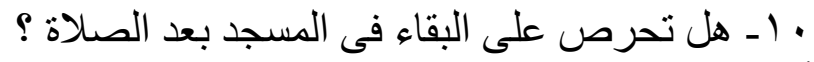

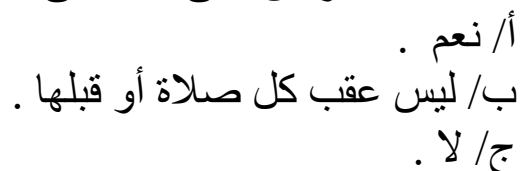

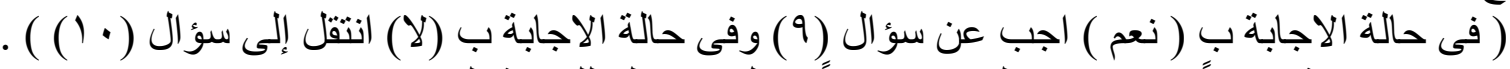

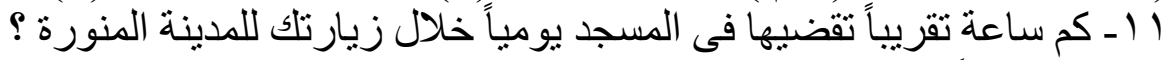
أ أراعة تقريباً.

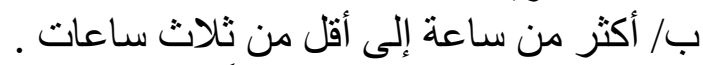

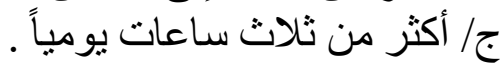

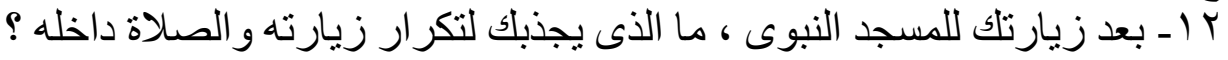

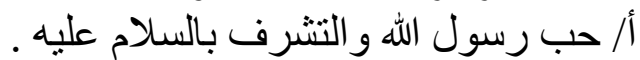

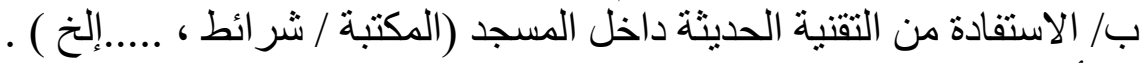

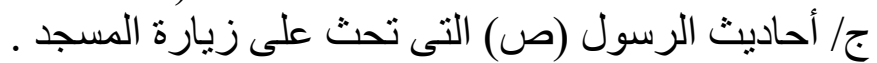

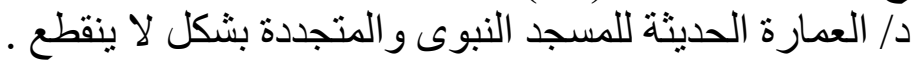

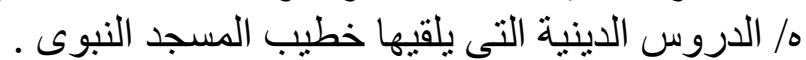

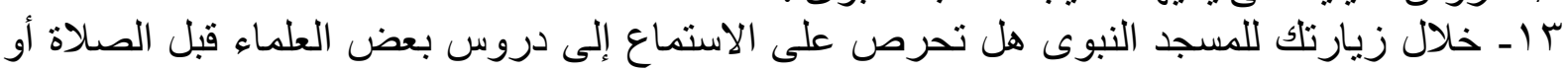

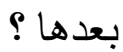

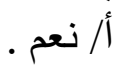

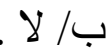
ـ ا ـ المصريون مأخوذون بأصو ات علماء وخطباء المسجد النبوى خاصة صوت د د عبد الرحمن السديس

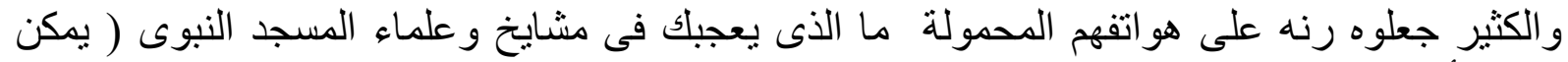

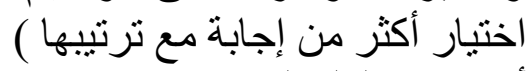

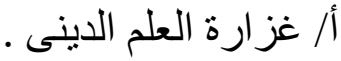

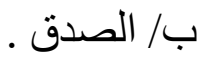

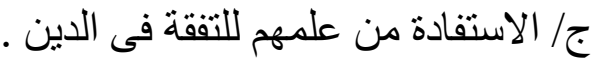

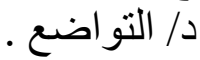

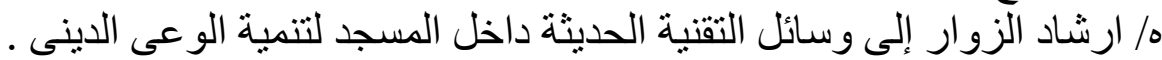

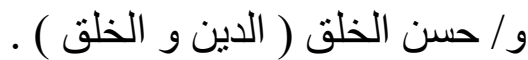
ا 1 ـ فى ر أيك ما أهم ما يستفيده المسلمون من زيارتهم للمسجد النبوى ؟

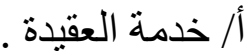

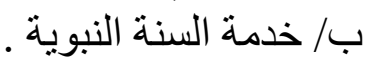

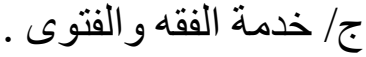
د/ زيارة مكتبة المسجد وتفقد الفوى أهم مقتنياتها . 


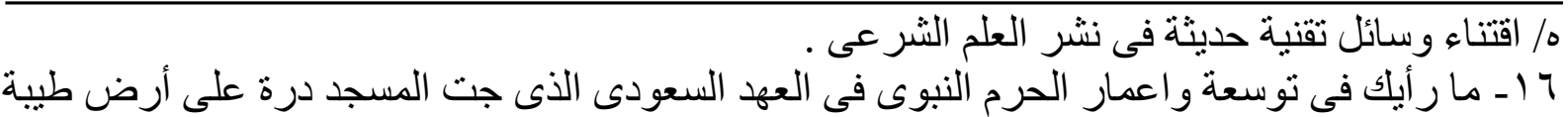

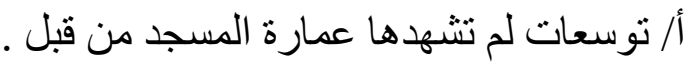
ب/ قدمت راحة كبيرة لزوار المسجد النبوى للبقاء داخله اكبر وقت للاستفادة من التقنيات الحديثة داخله .

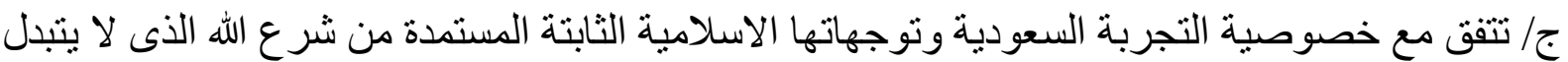
و لا يتغير ولا يتأثثر بسياسة أو غير ها ، و التى وضع لبنتها لتونها الأولى الرسول (ص) .

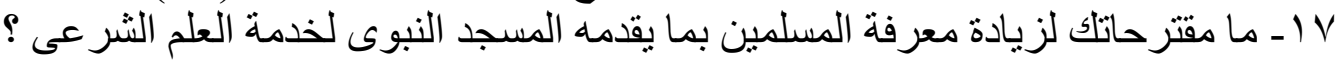

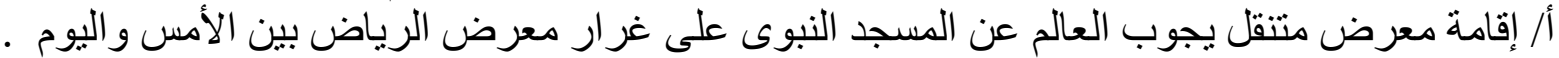
ب/ توزيع نشرات وكتيبات عن المسجد والاهتمام بالإعلام الجديد فى توعية المسلمين بأهمية المسجد النبوى . ج/ إقامة ندو ات داخلية وخارجية عن فضل المسجد النبوى . د/ أخرى تذكر. 1 ا ـ هل هنالك ما أز عجلك أو أشعرك بعدم الارتياح خلال زيارتك للمسجد النبوى . ( فى حالة الاجابة ب (نعم) أذكر أهم هذه العو امل التى اشعرتلك بالانز عاج أو عدم الإرتياح ) .

مع تقديم و افر الثكر والتحية والامنيات .

(الباحثه) 